IZA DP No. 7431

Proximity and Coresidence of Adult Children and their Parents in the United States:

Description and Correlates

Janice Compton

Robert A. Pollak

May 2013 


\title{
Proximity and Coresidence of Adult Children and their Parents in the United States: Description and Correlates
}

\author{
Janice Compton \\ University of Manitoba \\ Robert A. Pollak \\ Washington University in St. Louis \\ and IZA \\ Discussion Paper No. 7431 \\ May 2013 \\ IZA \\ P.O. Box 7240 \\ 53072 Bonn \\ Germany \\ Phone: +49-228-3894-0 \\ Fax: +49-228-3894-180 \\ E-mail: iza@iza.org
}

\begin{abstract}
Any opinions expressed here are those of the author(s) and not those of IZA. Research published in this series may include views on policy, but the institute itself takes no institutional policy positions. The IZA research network is committed to the IZA Guiding Principles of Research Integrity.

The Institute for the Study of Labor (IZA) in Bonn is a local and virtual international research center and a place of communication between science, politics and business. IZA is an independent nonprofit organization supported by Deutsche Post Foundation. The center is associated with the University of Bonn and offers a stimulating research environment through its international network, workshops and conferences, data service, project support, research visits and doctoral program. IZA engages in (i) original and internationally competitive research in all fields of labor economics, (ii) development of policy concepts, and (iii) dissemination of research results and concepts to the interested public.
\end{abstract}

IZA Discussion Papers often represent preliminary work and are circulated to encourage discussion. Citation of such a paper should account for its provisional character. A revised version may be available directly from the author. 


\section{ABSTRACT \\ Proximity and Coresidence of Adult Children and their Parents in the United States: Description and Correlates}

In this paper we provide an overview of the patterns of intergenerational proximity and coresidence of adult children and their mothers in the U.S., using data from the National Survey of Families and Households (NSFH) and the U.S. Census. We highlight the importance of three specification and sample choices in the analysis. First, most previous studies consider coresidence to be the limiting case of proximity, using Tobit, ordered logit, or ordered probit specifications. We argue that proximity and coresidence are qualitatively different, and show that the multinomial logit provides a better representation of the patterns in the data. Second, we argue that substantial differences in the correlates of proximity by gender and marital status indicate the importance of modeling these categories separately. Third, the NSFH allows us to consider the proximity of couples to both his mother and her mother. This information is rarely available in survey data but is important for complete analyses. Our results show that education and age are the most robust predictors of proximity: college graduates are less likely to live near their mothers and older children live further from their mothers. Other demographic variables such as race, ethnicity and only child status also affect the probability of close proximity and coresidence. However, characteristics indicating adult children's current need for transfers (e.g. grandchildren) are not correlated with either close proximity or coresidence, while characteristics indicating mothers' current needs for transfers (e.g., disability) are correlated with coresidence but not close proximity.

JEL Classification: $\quad \mathrm{J} 10$

Keywords: family proximity, intergenerational transfers

Corresponding author:

Robert A. Pollak

Washington University

Olin Business School

Department of Economics

Campus Box 1133

1 Brookings Drive

St. Louis, MO 63130

USA

E-mail:pollak@wustl.edu 


\section{Introduction}

Across the developed world there is an increasing need for non-parental childcare, due to increases non-marital fertility, divorce, and the labor force participation of mothers, and an increasing need for long-term care of the disabled elderly, due to increasing life expectancy. When coupled with declining social spending, the burden of caregiving is likely to be increasingly placed on family members who reside with or near those in need of care. For this reason, the determinants and consequences of family proximity is a growing field of study in economics and other social sciences.

In this paper we provide an overview of the patterns of proximity and coresidence involving adult children and their mothers in the United States. We then look for evidence of a relationship between the current need for intergenerational transfers of care and the distance between adult children and their mothers. To the extent that individuals respond to changing needs for care by migrating, we would expect to see stronger patterns of coresidence and close proximity among family members most in

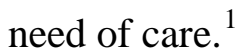

Our analysis builds on past work on proximity and coresidence in three directions. First, we distinguish clearly between coresidence and close proximity, arguing that this distinction is important both for theoretical and empirical reasons. Second, we analyze the determinants of proximity separately for men and women, married and unmarried. Characteristics influencing proximity differ across these

\footnotetext{
${ }^{1}$ We focus on proximity to mothers rather than fathers because mothers are more likely than fathers to provide and to receive hands-on care: grandmothers are more likely than grandfathers to care for grandchildren, and elderly mothers are more likely than elderly fathers to receive long-term care from adult children. If both parents are alive and living together, the distinction between proximity to mothers and proximity to fathers disappears. Only 10 percent of the adult children in the sample we use (NSFH) report that both of their parents are alive but not living together. Although we could look at fathers who do not
} 
samples; by combining them we would lose information. Third, we are able to consider the proximity of couples to both his mother and her mother, information that is rarely collected in data. For provision and receipt of care, it is important to distinguish among couples that are located close to both mothers, close to her mother only, close to his mother only, and close to neither mother.

Demographers, sociologists, and economists generally focus on migration rather than proximity. Although proximity patterns are the result of migration behavior of adult children and their parents, these behaviors are usually studied separately. Konrad et al. (2002) and, following their lead, Rainer and Siedler (2009), focus on the migration of siblings and the resulting patterns of proximity. Konrad et al. develop a model in which older siblings are more likely to move away from their parents to avoid the burden of caring for the parents when they become elderly and disabled. Although both Konrad et al. and Rainer and Siedler emphasize the burden that close proximity imposes on adult children, adult children may also benefit from close proximity (e.g., from child care). If adult children benefit from childcare early in their adult lives and elderly parents benefit from long-term care late in their lives, the balance of benefits and burdens for adult children who live continuously with or in close proximity to their parents will vary predictably over the life cycle.

If proximity is influenced by the current need for care, we might expect closer proximity when young grandchildren are present and when mothers are older and in poor health. We find weak, non-existent and, in some cases, negative relationships between close proximity and variables indicating the need for hands-on care. We focus on the

live with mothers such a project immediately raises the issue of stepfathers and stepmothers. Pezzin, Pollak, and Schone (2008) discuss stepparents, stepchildren and long-term care. 
need for hands-on care rather than on monetary transfers because intergenerational transfers involving money require neither close proximity nor coresidence, but transfers involving hands-on care (e.g., of grandchildren or the disabled elderly) do require close proximity or coresidence. ${ }^{2}$ Glaser and Tomassini (2000) attempt to assess the relative importance of long-term care and childcare as motives for proximity in Italy and Britain. They find that in Italy the adult children's characteristics were a more important correlate of intergenerational proximity than parents' characteristics, but in Britain parents' characteristics were more important than those of adult children.

Most previous studies of proximity have used the elderly parent as the unit of observation and considered the distances between adult children and their parents, using the adult children's marital status as a control variable; examples include Glaser and Tomassini (2000), Shelton and Grundy (2000), Rogerson, Burr and Lin (1997), Silverstein (1995), Lin and Rogerson (1995), Clark and Wolf (1992). When the question addressed involves care of a disabled elderly parent, whether one or more adult children lives in close proximity to the parent is of primary importance. When the question addressed involves life-cycle patterns of intergenerational transfers and, perhaps, reciprocity, the life-cycle pattern of proximity for adult children is of primary importance. Because these life-cycle patterns are our focus, we use the adult children as the unit of observation. ${ }^{3}$ Rogerson, Weng and Lin (1993) also use adult children as the unit of observation. Unlike Rogerson, Weng and Lin, however, we distinguish sharply between coresidence and proximity, between unmarried and married adult children and, for married adult children, between his mother and her mother. Løken, Lommerud and

\footnotetext{
${ }^{2}$ Supervision and monitoring of hands-on care also require close proximity or coresidence if the individual receiving care is unable to supervise and monitor it (e.g., because of age or cognitive impairment).
} 
Lundberg (2013) analyze the location decisions separately for married and unmarried men and women in Norway. Using the National Registry data they are able to link a full cohort of Norwegian couples to their locations and to the locations of the parents of both partners.

Hands-on care requires close proximity, but not necessarily coresidence. Michael, Fuchs and Scott (1980), Costa (1999), and Ruggles (2007) document the decline in intergenerational coresidence in the United States, although they offer different explanations for its decline. The two earlier studies argue that the decline is primarily the result of the increased affluence of elderly parents who, following the introduction of social security, were able to exercise their preference for independent living. Ruggles disagrees, arguing that the decline in coresidence is the result of the increased affluence of adult children, a consequence of increased wage labor, mass education, and the declining importance of household production. Regardless of the reasons for the decline in coresidence, intergenerational exchanges, to the extent that they take place, are increasingly likely to take place across households rather than within households. A substantial literature has analyzed coresidence, but proximity has not yet received the attention it deserves.

We say that an adult child lives in "close proximity" to his or her mother if they live within 30 miles of each other but do not live in the same household. Thus, in our terminology, coresidence is not a special case of "close proximity." The sharp distinction between proximity and coresidence is crucial because proximity and coresidence differ discontinuously in their implications for cost and privacy. Coresidence with one's mother or mother-in-law and living one mile away differ in dimensions that living one

\footnotetext{
${ }^{3}$ Choi (2009) uses PSID data to investigate life-cycle patterns of proximity.
} 
mile away and two miles away do not. Living in the same household saves money, but patterns of coresidence and proximity suggest that, for most families, these savings are outweighed by the loss of privacy. Using data from the National Survey of Families and Households (NSFH), we find that coresidence of adult children and their parents is associated with different variables than close proximity, so neither the theory nor the data support treating coresidence as a limiting case of close proximity.

We treat separately married and unmarried adult children for both theoretical and empirical reasons. Theory suggests that migration and location decisions of married adult children are taken jointly with spouses whose preferred locations may differ from theirs because of career or family considerations. Furthermore, when mothers and mothers-in-law live far apart, a couple cannot live close to both his mother and her mother. The need to distinguish between married and unmarried adult children is underscored by our findings about the proximity of women and their mothers. Pooling all adult children and controlling for marital status, we find no impact of gender on proximity or coresidence. When we separate the sample by marital status, however, we find that gender is a strong correlate of coresidence: unmarried women are far less likely than unmarried men to live with their mothers.

To investigate the extent to which patterns of intergenerational proximity and coresidence are gendered, we treat separately the distances between a couple and her mother and between a couple and his mother. We see higher levels of time transfers between daughters and mothers than between sons and mothers, suggesting that the relationship between transfers and proximity differs by gender.

Following a brief description of the data, we discuss the relationship between 
proximity, coresidence and intergenerational time transfers. Unsurprisingly, time transfers are strongly related to close proximity, and there is a positive relationship between the disability of parents and coresidence. We next describe proximity in the U.S., highlighting the dominant role of education in the observed patterns. Then, using regression analysis, we examine the correlates of coresidence and close proximity between adult children and their mothers. We find that coresidence is more likely when mothers are most likely to need care - when they are older, in poor health and unmarried. But we find the probability of close proximity depends primarily on age and education of the adult child, not on the presence of young children or on characteristics that might indicate the mothers' need for care. We end with a brief conclusion.

\section{Data}

We use data from the second wave of the National Survey of Families and Households (NSFH) (Sweet and Bumpass, 1996). The original survey (1987-1988) includes a sample of 13007 households, with an oversampling of blacks, Puerto Ricans, Mexican Americans, single-parent families, families with stepchildren, cohabiting couples, and recently married couples. Wave 2, with interviews conducted in 1992-1994, is a five-year follow-up of the original survey. ${ }^{4}$ The primary respondent was randomly selected from the adults in the household. Both the primary respondents and their spouses or partners were asked to complete the entire survey. We include cohabiting

\footnotetext{
${ }^{4}$ We use wave 2 rather than wave 1 because it is more recent data. We did not use the data from wave 3 (2002-2004) because the sample for wave 3 was cut drastically and nonrandomly. Sample inclusion required that the respondents had a child over the age of 3 in wave 1 or were 45 years of age or older. Spouses were only interviewed for wave 3 if they were present in wave 1 (i.e., if the primary respondent married between wave 1 and wave 3 , the new spouse was not interviewed.)
} 
heterosexual couples in the "married" category. ${ }^{5}$ The category "unmarried" includes those who are never married, divorced, widowed, or separated. Wave 2 collected information about the parents of both the respondent and the respondent's spouse or partner. Mothers' information includes distance from the respondent, marital status, health status and contact with the respondent. We analyze two sub-samples: all unmarried individuals aged 25 and older whose mothers are Alive and Living in the

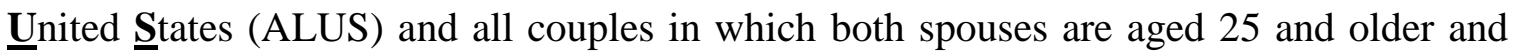
the mother of at least one spouse is ALUS. Thus, our analysis excludes American residents whose mothers are deceased or live outside the U.S.

In addition, we include summary statistics on coresidence from the 2000 Integrated Public Use Census (IPUMS) (Ruggles et al. 2009). As the Census data does not include information on family proximity, we use the birth state of individuals as a proxy variable. We also use census data to describe patterns of coresidence and disability.

\section{Proximity, Coresidence and Intergenerational Time Transfers}

Before analyzing the correlates of coresidence and proximity, we consider the relationship between intergenerational time transfers and distance. One reason economists study family proximity is to investigate the effect of family proximity on time use patterns and expenditure patterns (e.g., how the availability of family to provide care affects labor supply and the purchase of childcare and elder care). The NSFH provides

\footnotetext{
${ }^{5}$ Although the NSFH does not include cohabitors in their marital status indicator, they are identifiable and the questionnaire given to cohabiting partners is the same as that given to legally married partners. In our sample, there are 441 cohabiting couples, approximately 10 percent of couples. We ignore same-sex couples because there are only 11 such observations in the data.
} 
information on transfers of time between adult children and their parents. ${ }^{6}$ For couples, NSFH reports transfers to and from both his parents and her parents. More specifically, NSFH reports time transfers given to or received from "mother," "mother and father," and "father." We refer to the sum of "mother" and "mother and father" as transfers between adult children and their mothers; this sum is the time transfer variable we analyze. For time transfers, the NSFH indicates whether the unmarried child or couple report providing the following categories of help to his mother or her mother in the past month: (1) shopping, errands, transportation; (2) housework, yard work, car repairs, other help around the house; (3) advice, encouragement, moral or emotional support. The NSFH also indicates whether the adult children report receiving help in these three categories from their mothers or mothers-in-law, as well as two additional categories of help received: (4) childcare while working and (5) childcare not while working.

Three patterns of intergenerational transfers are evident from table 1 which shows the percentage of the sample who report giving or receiving help from their mothers. ${ }^{7}$ First, and unsurprisingly, time transfers are more likely when mothers and children live in close proximity. Second, the positive correlation between time transfers and close proximity holds not only for transfers that require physical presence, but also for

\footnotetext{
${ }^{6}$ NSFH asks about transfers between the respondent and individuals not living in the same household. Therefore the sample includes all adult children not currently living with their mothers. The NSFH also includes information about monetary transfers between respondents and their parents. We included these transfers in the analyses but obtained weak and non-robust results. This may in part be due to the survey design. Respondents are asked whether they received or gave a gift over the amount of $\$ 200$ at any one time in the past 12 months. Smaller amounts given over the course of the year would not be captured. Also, for monetary transfers we cannot distinguish between gifts coming from mother and those coming from father, because the coding only lists "parents." This is a potential problem for the 10 percent of cases in which parents are not living together. We have focused on time transfers, because monetary transfers require neither coresidence nor close proximity.

${ }^{7}$ In this section we combine married children with both mothers ALUS and married children with one mother ALUS.
} 
emotional help. Third, the pattern of transfers is gendered: the probability of time transfers from and to her mother exceeds that from and to his mother in all categories. ${ }^{8}$

Regression analyses (not shown) indicate that the patterns described above continue to hold when controls are added - time transfers between adult children and their mothers are strongly associated with proximity and with the gender of the adult child. ${ }^{9}$ Additionally, adult children receive time transfers when they are younger and have children of their own, and when their mothers are not in poor health. Adult children are more likely to provide time transfers when they are older and when their mothers are in poor health and unmarried.

While the NSFH does not provide comparable information about transfers between those living in the same household, coresidence of an elderly parent with an adult child is often associated with disability of the parent or of the adult child. Table 2 presents data from 2000 U.S. Census on the disability characteristics of those aged 65 and over by their living arrangements. The categories are ordered from left to right from the highest average proportion of disability to the lowest. This ordering shows the strong relationship between household organization and disability status. The groups with the highest proportion of disabilities are individuals who do not own or rent their current residence. ${ }^{10}$ The individuals in columns (A) and (B) live in institutions; those in columns (C) and (D) live with their adult children in the children's households. Those in columns

\footnotetext{
${ }^{8}$ This is consistent with the findings of Duflo (2000), who investigated the effect of the South African Old Age Pension that was extended to black South Africans in the early 1990s after the end of apartheid. Duflo found that the well-being of grandchildren, especially granddaughters, was more strongly related to pension payments received by their maternal grandmothers than those received by their paternal grandmothers. Duflo finds that pension payments received by grandfathers had little or no effect on grandchildren.

${ }^{9}$ The regressions are available from Janice Compton, comptonj@cc.umanitoba.ca.

${ }^{10}$ In prior language, these are individuals who are neither "head of household" nor "spouse of head." Beginning in 1980 the census questionnaire no longer referred to a "head of household," specifying instead
} 
(E) to $(\mathrm{H})$ have lower levels of disability and are the owners or renters in their own households. Although coresidence is often studied in conjunction with long-term care, with the exception of the unpartnered (e.g., widowed; divorced) disabled elderly, the frequency of coresidence is low. Adult children who live with their parents are also more likely to be disabled than those who do not live with their parents. In 2000, 18.3 percent of women and 20.2 percent of men aged 30-60 whose mothers were not in the same household reported a disability, while 27.7 percent of women and 30.7 percent of men in the same age group whose mothers were in the same household reported a disability. ${ }^{11,12}$ To summarize: there is a strong relationship between close proximity of adult children and their mothers and the transfer of general and emotional help. Additionally, coresidence is strongly related to disability of the mother or the adult child. In the regression analyses that follow, we investigate whether the characteristics that indicate a need for time transfers are also correlated with close proximity.

\section{Proximity of Adult Children and their Mothers}

Most adult Americans live close to their mothers. Table 3 provides information on the full distribution of distances from the NSFH. For married couples, the median distance from his mother is 25 miles and the median distance from her mother is 20 miles. Thus, there is a gender effect, with married couples living somewhat closer to her

\footnotetext{
the designation of "person one"--the first person listed on the census form. This reference person could be any household member in whose name the property was owned or rented.

${ }^{11}$ This includes all U.S. Census respondents who indicated any of the following disabilities: disability that causes difficulty working, difficulty with mobility, personal care limitation, physical difficulty, memory difficulty, and hearing or seeing difficulty

${ }^{12}$ Many adult children who coreside with their elderly mothers have never left home. Using the PSID, Hotz, McGarry, and Wiemers (2008) find that "Even by age 85, 7 percent of widows are living with children who are not observed to have left their parents' household after 1968, and this arrangement constitutes one-fifth of those children living with their parents (p. 17)."
} 
mother than to his. These distances are relatively insensitive to whether we include or exclude coresidence from the sample because few married couples live with her mother or his mother. For unmarried individuals, however, especially for unmarried men, the median distances are quite sensitive to the treatment of coresidence: if we include coresidence (as distance $=0$ ) in the calculation, the median distance between unmarried men and their mothers is 5 miles, while if we exclude coresidence, the median distance is 15 miles. For unmarried women, the corresponding medians are 8 miles and 15 miles. Thus, for unmarried individuals, we find a gender difference only when coresidents are included, because coresidents are more likely to be unmarried men.

The probability that individuals live close to their mothers is strongly related to education. Census data provides a first look at this issue. The U.S. Census does not report distance from mother, but it does report the state in which individuals were born. ${ }^{13}$ Figure 1 shows the percentage of U.S. born adults living in their birth state in $2000 .{ }^{14}$ At age 30, 63 percent of native-born adults reside in their birth state. The proportion living in their birth state ranges from only 52 percent for those with a college degree to 71 percent for those with a high school diploma or less. This 19 percentage point difference between those with a college degree and those with a high school education or less also holds for the elderly. At age 75, 56 percent of U.S. born adults reside in their birth state, 45

\footnotetext{
13 Rosenbloom and Sundstrom (2003) use residence in birth state to analyze migration patterns from 1850 1990. They find that about 60-65 percent of the sample live in their birth state, and that the probability of living in one's birth state is negatively correlated with age and education. Gender differences in migration patterns are not observed by the end of their sample period.

${ }^{14}$ Data from the Panel Study of Income Dynamics (PSID) substantiates our claim that birth state and distance to mother are related: in 1988 the PSID reports grouped distance to mother and "State where the Head grew up." Although the state of birth and the state where one grows up do not necessarily coincide, there is a strong negative relationship between residing in the state where one grew up and distance to mother. Of those heads currently residing in their childhood state, more than half live within 10 miles of their mothers and less than 15 percent live more than 100 miles away; of those heads not living in their
} 
percent of those with a college degree and 64 percent of those with a high school education or less. Because interstate migration peaks when individuals are in their mid20s, this education gap does not close. ${ }^{15}$

The observed relationship between education and proximity is due in part to the fact that couples with more education are less likely to have mothers who live close to each other. Spouses whose mothers live far apart cannot locate near both his mother and her mother. Spouses' resolution of this marital co-location problem has implications for childcare, for long-term care of the disabled elderly, and for married women's labor force participation; we examine the implications for labor force participation in Compton and Pollak (forthcoming).

In 2000, 59 percent of all married couples aged 25 and older consisted of spouses born in the same state (table 4, top panel). This proportion differs with education. For "power couples" -- terminology introduced by Costa and Kahn (2000) to describe couples in which both spouses hold college degrees -- only 46 percent were born in the same state. For low-power couples - couples in which neither spouse holds a college degree - 64 percent were born in the same state. ${ }^{16}$ These figures have remained fairly constant from 1980 through 2000, while the proportion of power couples in the census population has increased from 9 percent in 1980 to almost 17 percent in 2000. If these

birth state only 16 percent live within 10 miles of their mothers and 70 percent live more than 100 miles away.

${ }^{15}$ Boyd et al. (2005) analyse the location decisions of teachers in New York State. They conclude: "In seeking their first teaching jobs, prospective teachers appear to search very close to their hometowns and in regions that are similar to those where they grew up. Location of college plays an independent, although less important, role in teachers' employment location decisions. These conclusions are supported by descriptive statistics and our estimated behavioral model. Moreover, these results are robust to several alternative specifications (p. 127)."

${ }^{16}$ For part-power couples in which only the husband has a college degree, 54 percent were born in the same state; for part-power couples in which only the wife has a college degree 57 percent were born in the same state. 
trends in education and marriage continue, the percentage of couples in which both spouses were born in the same state will continue to decline. ${ }^{17}$

Census data also show that the probability that a couple lives in the birth state of one or both spouses declines with education (table 5, top panel). In 2000, 53 percent of low-power couples lived in the birth state of both spouses, compared with only 33 percent of power couples. These numbers are almost unchanged from the previous decade. ${ }^{18}$

Although the variables in NSFH and the census are not identical, the two datasets tell similar stories. When using the NSFH data, we say that adult children live "in close proximity to" or "close to" their mothers if they live within 30 miles of their mothers but do not coreside with them. We say that adult children who live more than 30 miles from their mothers live "far from" her. ${ }^{19}$ The bottom panel of table 5 shows the proximity of married couples with various levels of education to his mother and to her mother. In NSFH we find that only 18 percent of power couples live close to both mothers, while 50 percent of low-power couples live close to both mothers. At the opposite extreme, almost half of power couples live far from both mothers, while only one-fifth of low-power couples live far from both mothers. ${ }^{20}$

\footnotetext{
${ }^{17}$ About 30 percent of individuals over 25 born after 1944 are college graduates, a percentage that has remained relatively stable over time. The percentage of college graduates declines rapidly among those born before 1944; see Stoops (2004).

${ }^{18}$ The census data show some evidence of a gender effect: while an equal percentage of couples live in her and in his birth state, for part-power couples the proportions living in the birth state of both or neither depends on which spouse has the college degree. Among couples in which only the husband has a college degree, 39 percent live in the birth state of both spouses while 36 percent live in the birth state of neither spouse. Among couples in which only the wife has a college degree, 47 percent live in the birth state of both spouses while only 26 percent live in the birth state of neither spouse.

${ }^{19}$ Other studies use similar cut-offs for distance. Robustness tests around this cut-off yielded similar results. A number of studies use temporal rather than distance measures; in the appendix we describe the variables used in other studies. We include county level measures of density, size of place, and commuting time to control for differences in travel time.

${ }^{20}$ Power couples and part-power couples in which the husband has a college degree are about as likely to live close to his mother as to her mother, but low-power couples and part-power couples in which the wife has a college degree are much more likely to live close to her mother than close to his.
} 
The regression results in the following sections confirm the robust negative association between education, on the one hand, and close proximity and coresidence, on the other.

\section{Proximity and Coresidence}

Proximity and coresidence differ qualitatively. If distance were the only relevant metric, then coresidence (distance $=0$ ) would be the limiting case of proximity. But distance is not the only relevant metric. For both adult children and elderly parents, living in the same household and living next door differ qualitatively because of their implications for cost and for privacy. Hence, we should expect the correlates of coresidence to differ from the correlates of close proximity. Recent empirical work, however, has often imposed on the data statistical models that require the correlates of close proximity to be the same as the correlates of coresidence. ${ }^{21}$ A number of papers, for example, Konrad et al. (2002) use distance categories (co-residence, same neighborhood, same city, etc) and ordinal models on the categories. Other papers, for example, Silverstein (1995), use Tobit models with coresidence as the limiting case. Still others, such as Clark and Wolf (1992), Shelton and Grundy (2000), and Løken, Lommerud and Lundberg (2013) combine the categories of coresidence and close proximity when using grouped data. Rainer and Siedler (2009) employ all three of these modeling techniques, using both a Tobit model on distance and an ordinal model with grouped distance variables, in the latter collapsing coresidence and close proximity into a single category. Lin and Rogerson (1995) and Rogerson, Weng and Lin (1993) exclude

\footnotetext{
${ }^{21}$ A more in depth literature review can be found in the working paper version of this paper. (http://www.mrrc.isr.umich.edu/publications/papers/pdf/wp215.pdf).
} 
coresidents from their sample, creating a sample selection issue that compromises the interpretation of their results. Rogerson, Burr and Lin (1997) use multinomial logit models to assess the correlates of convergence and divergence in proximity. Only Glaser and Tomassini (2000) use the multinomial logit to model the correlates of proximity and coresidence, although they do not test the multinomial logit against alternative specifications.

Our descriptive regressions confirm the need to treat separately coresidence and close proximity rather than treating coresidence as a limiting case of proximity. Tobit and logit treat coresidence as a limiting case of proximity, while the multinomial logit does not. Table 6 presents the results of regressions on proximity and coresidence for the full sample, including both married and unmarried adult children. Column (A) shows the coefficients from a Tobit regression in which the dependent variable is distance from mother, treating coresidence as the limiting case of proximity. Column (B) presents the results from a logit regression in which the dependent variable equals one if the individual coresides with, or lives in close proximity (i.e., within thirty miles) to, his or her mother. We present the logit coefficients as odds ratios. Column (C) presents the results from a multinomial logit regression, our preferred specification, in which the dependent variable includes three alternatives: to coreside, to live close to, or to live far from.

The empirical results of this section confirm the superiority of the multinomial logit specification. The Tobit and logit specifications constrain regressors to affect living with mother and living close to mother in the same direction, but for some characteristics, the data are not consistent with these a priori constraints (e.g., Hispanic ethnicity; marital 
status of the mother). Because the multinomial logit does not impose these constraints, it provides a better description of the patterns in the data.

For certain variables - education, age, gender and siblings - the results from the three models tell a consistent story. Adult children with college degrees are much less likely to live with or near their mothers. Younger adult children are more likely, and older adult children are less likely, to live with or near their mothers. Gender has no impact on proximity or coresidence. Finally, compared to second-born or higher order children, only children are more likely to live with their mothers or close to them. ${ }^{22}$ There are, however, a number of differences across columns.

Consider ethnicity and race. For Hispanics, different regressions suggest different patterns. From the Tobit results alone, we would conclude that Hispanics live farther from their mothers. From the logit results alone, we would conclude that the Hispanic ethnicity has no significant effect (i.e., is the same as white, the omitted category). The multinomial logit, which imposes fewer a priori restrictions than the Tobit or logit, shows that compared with whites, Hispanics are no more likely to live in close proximity to their mothers, but twice as likely to live with their mothers. Unlike Hispanics, for blacks the three regressions tell very similar stories: blacks are more likely to live near their mothers and more likely to live with their mothers.

The multinomial logit also provides a more nuanced view of the effect of marital status. From the Tobit results alone, we would conclude that, compared with never married adult children, both married and previously married children live farther from their mothers. The multinomial logit shows that this conclusion rests solely on the lower 
probability of coresidence among married and previously married adult children and not on proximity. Finally, unlike Konrad et al. (2002) who find that first-born children are less likely than second born children to live close to their parents, our multinomial logit results suggest that first-born children are slightly more likely than later born children to live close to their mothers. This conclusion is not evident from the Tobit or the logit results. Our findings are consistent with those of Rainer and Siedler (2009) who find a sibling effect (only children live closer to their mothers, on average) but no birth order effect.

For mothers' characteristics, the multinomial logit again paints a different picture than the Tobit or logit. The Tobit results would lead us to conclude that only the marital status of mothers predicts distance. The multinomial logit shows that adult children are less likely to live close to mothers with college degrees, less likely to live with mothers in poor health, and more likely to live with mothers 75 years of age and over.

\section{Proximity of Adult Children to their Mothers}

The regressions in the previous section demonstrate the importance of treating separately coresidence and close proximity. Tables $7 \mathrm{a}$ and $7 \mathrm{~b}$ present the results of multinomial logit regressions that model whether adult children live with, close to, or far from their mothers. These regressions are similar to column (C) in table 6, but here we run them separately by gender and marital status. Since both migration patterns and transfers of care differ by gender and marital status, it is reasonable to consider these

\footnotetext{
${ }^{22}$ We categorize birth order in three mutually inclusive categories: only children, first born children with siblings and second or higher order children. Therefore, the coefficient on only child status is in
} 
samples separately when analyzing the determinants of proximity and coresidence. To facilitate comparisons with previous studies, we omit spousal characteristics in section VI.1 and introduce them in section VI.2. Although gender does not influence the probability of living in close proximity to one's mother, it does affect the probability of coresidence. Unmarried adult men are more likely than unmarried adult women to coreside with their mothers. Married adult women are more likely than married adult men to coreside with their mothers, but this gender effect is less important because married adult children are very unlikely to coreside with a parent.

\section{VI.1 Individual regressions}

As evidenced by the descriptive statistics, educational attainment is the most consistent correlate of close proximity of the adult children to their mothers. Adult children with college degrees are much less likely to live near or with their mothers. ${ }^{23}$ This may be true for at least four reasons. First, young adults may leave home to attend college and not return. Second, as shown in section IV, college educated couples are less likely to come from the same state; without a common birth state, they are more likely to live far from both mothers. Third, the college educated may participate in a geographically wider labor market and, therefore, are more likely to move away for employment. Fourth, if college educated adult children are more successful in employment and earnings, time transfers to and from mothers may be less important to them.

Controlling for the adult child's education, adult children are also less likely to

comparison to second-born or higher order children and not to all children with siblings.

${ }^{23}$ The effect is stronger for men, especially unmarried men. 
live near their mothers if their mothers have a college degree. There are at least three possible explanations for this correlation. First, mothers with college degrees are more likely to live away from their own families of origin and this may affect the location decisions of their adult children. This may operate through a demonstration effect or by weakening the adult child's incentive to remain because there are fewer extended family members in close proximity. Second, mothers with more education may be better able to afford market substitutes for hands-on care by their adult children. Third, the mother's education may affect the children's location decisions if it affects the mother's value of time and, hence, her willingness to provide childcare. When we split the sample by gender, we find that the effect of mother's education is significant only for daughters, suggesting that the demonstration effect and/or the willingness to provide childcare may be driving this result.

The age of the adult child is also an important and robust correlate of both proximity and coresidence. Regardless of marital status, younger adult children (aged 2534) are more likely to live near and, for the unmarried, more likely to live with their mothers, compared with the base group (aged 35-44). Older adult children (aged 45 and older) are less likely to live with and near their mothers, although this result is not always significant.

The regressions also show patterns by race and ethnicity. Compared with their white counterparts, blacks are more likely to live with and near their mothers. Hispanics are more likely to live with their mothers, but are no more likely to live near them. In terms of coresidence the higher probability of coresidence for both blacks and Hispanics is driven by higher coefficients for unmarried men and married women. 
Our results confirm the negative effect of siblings on proximity. Only children are more likely to live closer to and with their mothers. This effect is stronger for women than for men; indeed, the results are not statistically significant for single men living near their mothers, nor for married men living either near or with their mothers. In contrast to Konrad et al. (2002), we do not find evidence that first-born children are less likely to live close to their mothers. ${ }^{24}$

Characteristics of adult children and characteristics of the mother that suggest a greater need for intergenerational transfers are not related to close proximity. We find no evidence that close proximity or coresidence is correlated with the presence of young children. Unmarried women with children are more likely to live near their mothers and less likely to coreside, compared to their counterparts without children, but the coefficients are not significant at conventional levels. The presence of young children has no discernible effect on the proximity of married respondents and their mothers.

Turning now to the characteristics of the mothers, for most variables we find no relationship between mothers' greater need for intergenerational transfers and close proximity. ${ }^{25}$ The exception is marital status: unmarried mothers are more likely to reside in close proximity to their adult children. Coresidence is more strongly related to mothers characteristics, with a strong gender pattern: women, both married and unmarried, are more likely to live with older mothers (aged 75 and over); married men are less likely to live near older mothers and unmarried men, the group most likely to live with their mothers, are less likely to live with mothers in poor health.

\footnotetext{
${ }^{24}$ In fact, we find that unmarried women who are first-born children are more likely to live close to their mothers.

${ }^{25}$ We ran similar regressions on the sample of respondents whose mothers and fathers were both alive, living in the U.S. and married to each other. The results were similar to the full sample results.
} 


\section{VI.2 Couple regressions}

In table 8, we restrict the sample to couples in which both mothers are alive and living in the $\underline{\text { United }}$ States (ALUS) and now add spousal characteristics to our analysis.

The strong results again come from age and education. Proximity declines as the age of the adult children increases and declines as education increases. ${ }^{26}$ Couples in which one or both spouses have a college degree are less likely to live close to their mothers. This result is weaker if only the wife has a college degree. ${ }^{27}$ Couples with children are slightly more likely to live near his mother, although the variable is not significant at conventional levels. The presence of children increases the probability that couples live with her mother, but very few married couples coreside with either his mother or her mother. Neither the presence of siblings nor birth order was significantly related to coresidence or close proximity in the couple regressions.

We now turn to the coefficients on the mothers' characteristics. Mothers' education lowers the probability of close proximity, but this is again only significant for proximity to her mother. None of the mothers' characteristics indicating need of care -poor health, old age (75 and over), and marital status (never married, divorced, widowed, or separated) -- are correlated with proximity. Coresidence is not correlated with

\footnotetext{
${ }^{26}$ With one exception: both younger and older couples are more likely to live with her mother than the comparison group (i.e., the middle group, adult children aged 35-44).

${ }^{27}$ This is consistent with Compton and Pollak (2007) in which we find that the effect of college education on couples' migration behavior is largely a male effect. Power couples and couples in which only the husband has a college degree are more likely to migrate compared with low-power couples and couples in which only the wife has a college degree. Løken, Lommerud and Lundberg (2013) find consistent results for Norway: couples are much more likely to live near his parents when the husband does not have a college degree, suggesting that location decisions are dominated by the education profile of husbands.
} 
mothers' health, but is positively related to old age, and marital status. ${ }^{28}$

Finally, the regression results show that when both mothers are ALUS and live in close proximity to each other, the adult children are likely to live close to them. Couples are more than three times more likely to live near her mother if they live near his mother and vice versa. This may reflect the strong gravitational pull factor of having both mothers in one location, but may also reflect differences in the propensity to migrate. If individuals from different locations meet and marry, one of them is likely to have migrated prior to their meeting. Hence, such couples are likely to have a greater than average propensity to migrate again. Furthermore, the migration, location, and proximity patterns of adult children may be more affected by networks of friends or the presence of extended family than by their mothers.

\section{Conclusion}

Hands-on care of children or the disabled elderly requires either close proximity or coresidence. As demographic and policy changes increase the need for intergenerational caregiving, it becomes increasingly important to understand the factors that influence family proximity. In this paper we describe and analyze the patterns of intergenerational proximity and coresidence of adult children and their mothers in the U.S., using data from the National Survey of Families and Households (NSFH) and the U.S. Census. Although intergenerational coresidence declined substantially in the United States during the twentieth century, many adult Americans live in close proximity to their

\footnotetext{
${ }^{28}$ Indeed, the coefficients on marital status indicate that couples are more likely to live with her (his) mother if her (his) mother is not married. There is also a cross effect. Couples are less likely to live with her (his) mother if his (her) mother is not married.
} 
mothers: the median distance between married adults and their mothers is less than 25 miles.

We find that education is the most robust predictor of proximity in both the raw data and in regression analyses: college graduates are less likely than other Americans to live near their mothers. We find that an adult child's age is also systematically related to close proximity: older children live further from their mothers. Other demographic variables such as race, ethnicity and only child status also affect the probability of close proximity and coresidence.

We do not find a measurable correlation between proximity and current need for transfers. Characteristics indicating adult children's current need for transfers (e.g. grandchildren) are not correlated with either close proximity or coresidence. Characteristics indicating mothers' current needs for transfers (e.g., disability) are not correlated with close proximity; their impact on coresidence depends on the gender and marital status of the adult child.

We highlight three specification choices that play crucial roles in the empirical analysis of proximity and coresidence. First, most previous studies that consider both proximity and coresidence use Tobit, ordered logit, or ordered probit specifications. We show that these specifications are misleading because they treat coresidence as the limiting case of close proximity, implying that the variables that predict close proximity are the same as the variables that predict coresidence. We argue that proximity and coresidence are qualitatively different, and that we should not expect the same variables to predict both. We show that the multinomial logit, which does not imply such restrictions, reveals patterns in the data that the Tobit, ordered logit and ordered probit 
specifications conceal.

Second, we find substantial differences in the correlates of proximity by gender and marital status, indicating the importance of modeling these categories separately. For example, when the samples are combined, we find that Hispanics are more likely than whites to live with their mothers. When the sample is split by gender and marital status, however, we find that this result is driven by single Hispanic men and married Hispanic women.

Third, the NSFH allows us to consider couples' proximity to both his mother and her mother. Although this information is rarely available in survey data, ignoring one set of parents can yield misleading results when modeling the relationship between proximity and intergenerational transfers of care. For example, Compton and Pollak (forthcoming) find that proximity to both mothers and mothers-in-law is an important determinant of the labor force attachment of married women with young children.

\section{ACKNOWLEDGEMENTS}

This paper is a revised version of University of Michigan Retirement Research Center Working Paper No. 2009-205, October 2009. The research reported herein was performed pursuant to a grant from the U.S. Social Security Administration (SSA) though the Michigan Retirement Research Center (Grant \# 10-M-98362-5-01) funded as part of the Reinvestment Research Consortium. The opinions and conclusions expressed are solely those of the authors and do not represent the opinions or policy of the Social Security Administration, any agency of the Federal government, or the Michigan Retirement Research Center. Earlier versions of this paper were presented at the NBER Cohort Studies workshop in Los Angeles, the PAA in New Orleans, the MRRC workshop, the Proximity, Coresidence, and Intergenerational Transfers workshop in Ann Arbor, SOLE in Boston, the Mothers and Retirement Workshop in Waterloo, ESPE in Seville, Macnet in Laguna Beach, the University of Illinois at Chicago, and the Johns Hopkins University. We are grateful to participants for their comments, to two anonymous referees, and especially to John W. R. Phillips.

Correspondence: Robert A. Pollak, Washington University in St. Louis, Olin Business School and Department of Economics, Campus Box 1133, 1 Brookings Drive, St. Louis, MO 63130

Email: pollak@wustl.edu 


\section{References}

Boyd, Donald, Hamilton Lankford, Susanna Loeb, and James Wyckoff, "The Draw of Home: How Teachers' Preferences for Proximity Disadvantage Urban Schools.” Journal of Policy Analysis and Management, Vol. 24, No. 1, (Winter 2005), 113-132.

Choi, HwaJung, "Adult Children's Proximity to Their Mothers: Cross-sectional and Lifecourse Aspects," Working Paper, August 2009.

Clark, Rebecca L. and Douglas A. Wolf, "Proximity of Children and Elderly Migration,” in Elderly Migration and Population Redistribution, edited by Adrei Rogers. London: Belhaven, 1992, 77-96.

Compton, Janice and Robert A. Pollak, "Why Are Power Couples Increasingly Concentrated in Large Metropolitan Areas?" Journal of Labor Economics, Vol. 25, No. 3, (July 2007), 475-512.

Compton, Janice and Robert A. Pollak, "Family Proximity, Childcare and Women's Labor Force Attachment," NBER Working Paper No. 17678. (December 2011), Journal of Urban Economics (forthcoming) .

Costa, Dora, "A House of Her Own: Old Age Assistance and the Living Arrangements of Older Nonmarried Women," Journal of Public Economics, Vol. 72, No. 1, (April 1999), 3959.

Costa, Dora L. and Matthew E. Kahn, "Power Couples: Changes in the Locational Choice of the College Educated, 1940-1990," Quarterly Journal of Economics, Vol. 115, No. 4, (November 2000), 1287-1315.

Duflo, Esther, "Child Health and Household Resources in South Africa: Evidence from the Old Age Pension Program," American Economic Review, Vol. 90, No. 2, (May 2000), 393-398.

Glaser, Karen and Cecilia Tomassini, "Proximity of Older Women to Their Children: A Comparison of Britain and Italy," The Gerontologist, Vol. 40, No. 6, (December 2000), 729-737.

Hotz, V. Joseph, Kathleen McGarry, and Emily Wiemers, "Living Arrangements among Elderly Women in the Panel Study of Income Dynamics," Working Paper, November 14, 2008.

Konrad, Kai, Harald Künemund, Kjell Erik Lommerud, and Julio R. Robledo, "Geography of the Family," American Economic Review, Vol. 92, No. 4, (September 2002), 981-998. 
Lin, Ge and Peter A. Rogerson, "Elderly Parents and the Geographic Availability of their Adult Children,” Research on Aging, Vol. 17, No. 3, (September 1995), 303-331.

Løken, Katrine, Kjell Erik Lommerud and Shelly Lundberg, "Your Place or Mine? On the Residence Choice of Young Couples in Norway,” Demography, Vol. 50, No. 1 (February 2013), 285-310.

Michael, Robert T., Victor R. Fuchs, and Sharon R. Scott, "Changes in the Propensity to Live Alone, 1950-1976," Demography, Vol. 17, No. 1, (February 1980), 39-53.

Pezzin, Liliana, Robert A. Pollak, and Barbara S. Schone, "Parental Marital Disruption, Family Type, and Transfers to Disabled Elderly Parents." Journal of Gerontology: Social Sciences. Vol. 63, No. 6, (November 2008). 340-358.

Rainer, Helmut and Thomas Siedler, "O Brother, Where Art Thou? The Effects of Having a Sibling on Geographic Mobility and Labor Market Outcomes.” Economica, Vol. 76, No. 303, (July 2009), 528-556.

Rogerson, Peter A., Richard H. Weng, and Ge Lin, "The Spatial Separation of Parents and their Adult Children.” Annals of the Association of American Geographers, Vol. 83, No. 4, (December 1993), 656-671.

Rogerson, Peter A., Jeffrey A. Burr, and Ge Lin, "Changes in Geographic Proximity between Parents and their Adult Children." International Journal of Population Geography, Vol. 3, No. 2, (June 1997), 121-136.

Rosenbloom, Joshua L. and William A. Sundstrom, "The Decline and Rise of Interstate Migration in the United States: Evidence from the IPUMS, 1850-1990," NBER Working Paper 9857, (July, 2003).

Ruggles, Steven, "The Decline of Intergenerational Coresidence in the United States, 1850-2000," American Sociological Review, Vol. 72, No. 6, (December 2007), 964-989.

Ruggles, Steven, Matthew Sobek, Trent Alexander, Catherine A. Fitch, Ronald Goeken, Patricia Kelly Hall, Miriam King, and Chad Ronnander. Integrated Public Use Microdata Series: Version 4.0 [Machine-readable database]. Minneapolis, MN: Minnesota Population Center [producer and distributor], 2009.

Shelton, Nicola and Emily Grundy, "Proximity of Adult Children to their Parents in Great Britain," International Journal of Population Geography, Vol. 6, No. 3, (June 2000), 181-195.

Silverstein, Merril, "Stability and Change in Temporal Distance between the Elderly and Their Children.” Demography, Vol. 32, No. 1, (February 1995), 29-45. 
Stoops, Nicole, "Educational Attainment in the United States: 2003," Current Population Reports, P20-550, June 2004.

Sweet, James A. and Larry L. Bumpass, The National Survey of Families and Households - Waves 1 and 2: Data Description and Documentation. Center for Demography and Ecology, University of Wisconsin-Madison (http://www.ssc.wisc.edu/nsfh/home.htm), 1996. 
Table 1: Incidence of Intergenerational Transfers, by Distance from Mother

\begin{tabular}{|c|c|c|c|c|c|c|c|c|}
\hline & \multicolumn{4}{|c|}{ Unmarried Sample } & \multicolumn{4}{|c|}{ Married Sample } \\
\hline & \multicolumn{2}{|c|}{ Men } & \multicolumn{2}{|c|}{ Women } & \multicolumn{2}{|c|}{ Her Mother } & \multicolumn{2}{|c|}{ His Mother } \\
\hline & $\begin{array}{l}\text { Less } \\
\text { than } 30 \\
\text { Miles }\end{array}$ & $\begin{array}{l}30 \text { Miles } \\
\text { or More }\end{array}$ & $\begin{array}{l}\text { Less } \\
\text { than } 30 \\
\text { Miles }\end{array}$ & $\begin{array}{l}30 \text { Miles } \\
\text { or More }\end{array}$ & $\begin{array}{l}\text { Less } \\
\text { than } 30 \\
\text { Miles }\end{array}$ & $\begin{array}{l}30 \text { Miles } \\
\text { or More }\end{array}$ & $\begin{array}{l}\text { Less } \\
\text { than } 30 \\
\text { Miles }\end{array}$ & $\begin{array}{l}30 \text { Miles } \\
\text { or More }\end{array}$ \\
\hline $\begin{array}{l}\text { Time Transfers } \\
\text { Help Received }\end{array}$ & & & & & & & & \\
\hline$\overline{\text { General help }}$ & 17.4 & 5.5 & 24.2 & 7.0 & 24.6 & 6.5 & 15.6 & 4.1 \\
\hline Emotional help & 56.5 & 50.7 & 61.4 & 53.6 & 60.9 & 41.4 & 52.7 & 32.4 \\
\hline Childcare while working & 32.2 & 5.7 & 38.1 & 8.2 & 21.4 & 2.7 & 16.3 & 1.9 \\
\hline Childcare other & 40.9 & 11.0 & 51.4 & 15.5 & 28.8 & 5.7 & 22.0 & 4.1 \\
\hline \multicolumn{9}{|l|}{ Help Given } \\
\hline General help & 53.6 & 13.8 & 54.1 & 18.1 & 52.8 & 12.6 & 49.5 & 10.0 \\
\hline Emotional help & 67.1 & 60.5 & 68.9 & 62.3 & 68.8 & 45.8 & 61.6 & 40.0 \\
\hline \multicolumn{9}{|l|}{ Money Transfers } \\
\hline Money received & 11.1 & 11.3 & 13.5 & 12.2 & 10.9 & 9.1 & 8.1 & 10.3 \\
\hline Money given & 5.1 & 5.6 & 5.6 & 4.7 & 5.4 & 3.8 & 3.8 & 4.1 \\
\hline Median amount received & 1200 & 1000 & 1000 & 1000 & 1000 & 1000 & 1000 & 1000 \\
\hline Median amount given & 400 & 750 & 400 & 700 & 400 & 500 & 450 & 1000 \\
\hline
\end{tabular}

NSFH Sample Wave 2. Sample includes adult children aged 25 and older, not coresiding with their mother. Sample for childcare categories includes only those respondents with children under the age of 12. General Help includes shopping, errands, transportation, housework, yard work, car repairs and other help around the house. 
Table 2: Characteristics of the Elderly (65+) by Living Arrangements

\begin{tabular}{|c|c|c|c|c|c|c|c|c|}
\hline \multirow[t]{3}{*}{ Characteristics of the Elderly } & \multicolumn{4}{|c|}{ Not Head or Spouse in Household } & \multicolumn{4}{|c|}{ Head or Spouse in Household } \\
\hline & \multicolumn{2}{|c|}{ Not Living with Children } & \multicolumn{2}{|c|}{ Living with Children } & \multicolumn{2}{|c|}{ Unmarried } & \multicolumn{2}{|c|}{ Married } \\
\hline & Married & Unmarried & Unmarried & Married & $\begin{array}{c}\text { Living with } \\
\text { Children }\end{array}$ & $\begin{array}{c}\text { Not Living } \\
\text { with } \\
\text { Children }\end{array}$ & $\begin{array}{l}\text { Living with } \\
\text { Children }\end{array}$ & $\begin{array}{l}\text { Not Living } \\
\text { with } \\
\text { Children }\end{array}$ \\
\hline Male & 37.0 & 32.1 & 14.7 & 54.9 & 19.1 & 24.6 & 60.4 & 55.7 \\
\hline Average age & 81.5 & 79.5 & 78.5 & 74.0 & 75.0 & 76.6 & 72.1 & 73.5 \\
\hline Grandchildren in house & 1.1 & 1.0 & 34.3 & 52.4 & 16.0 & 0.9 & 15.1 & 0.9 \\
\hline Disability causes difficulty working & 69.7 & 50.1 & 38.4 & 26.3 & 23.5 & 20.3 & 16.6 & 13.6 \\
\hline Disability causes difficulty with mobility & 71.5 & 52.7 & 43.6 & 27.4 & 26.8 & 24.1 & 17.6 & 14.0 \\
\hline Personal care limitation & 60.3 & 41.1 & 26.7 & 14.6 & 13.9 & 10.5 & 7.7 & 6.0 \\
\hline Physical difficulty & 72.1 & 55.6 & 50.9 & 32.9 & 38.2 & 33.3 & 25.7 & 22.1 \\
\hline Memory difficulty & 51.0 & 36.7 & 28.6 & 19.0 & 14.4 & 11.7 & 9.2 & 7.1 \\
\hline Vision or hearing difficulty & 33.2 & 26.9 & 26.4 & 17.9 & 16.4 & 15.7 & 12.5 & 11.5 \\
\hline Average & 59.6 & 43.8 & 35.8 & 23.0 & 22.2 & 19.3 & 14.9 & 12.4 \\
\hline Category percentage & 2.85 & 5.91 & 4.08 & 1.12 & 4.85 & 30.17 & 6.45 & 44.58 \\
\hline Sample size & 11032 & 21905 & 14343 & 3845 & 17923 & 110195 & 23789 & 167217 \\
\hline
\end{tabular}


Table 3: Weighted Proximity Distribution, By Marital Status and Gender

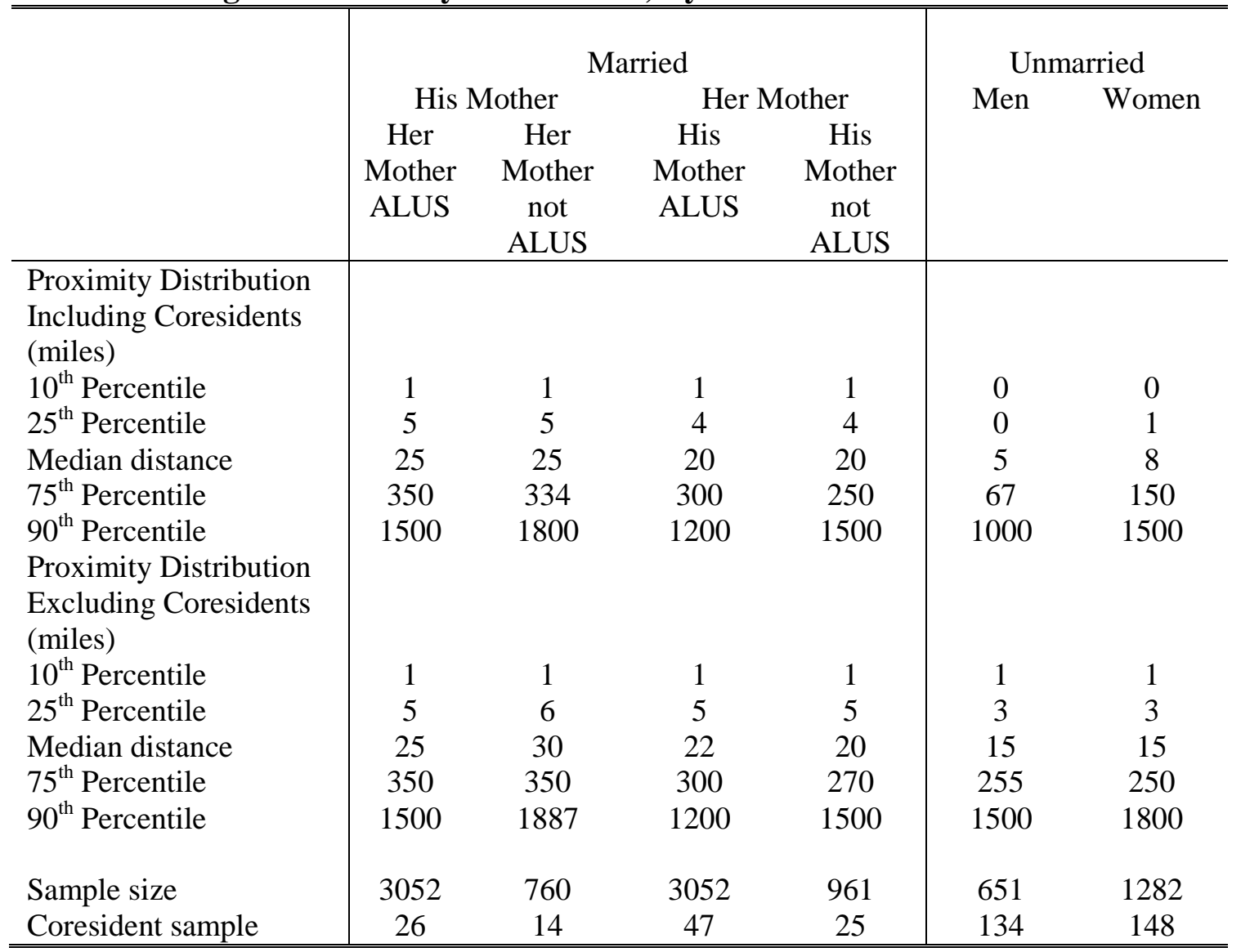

NSFH Second Wave. Sample includes all individuals aged 25 years and older whose mother is ALUS and all couples in which both spouses are aged 25 and older with at least one mother ALUS. 
Figure 1: Proportion of U.S. Born Residents Living in their Birth State

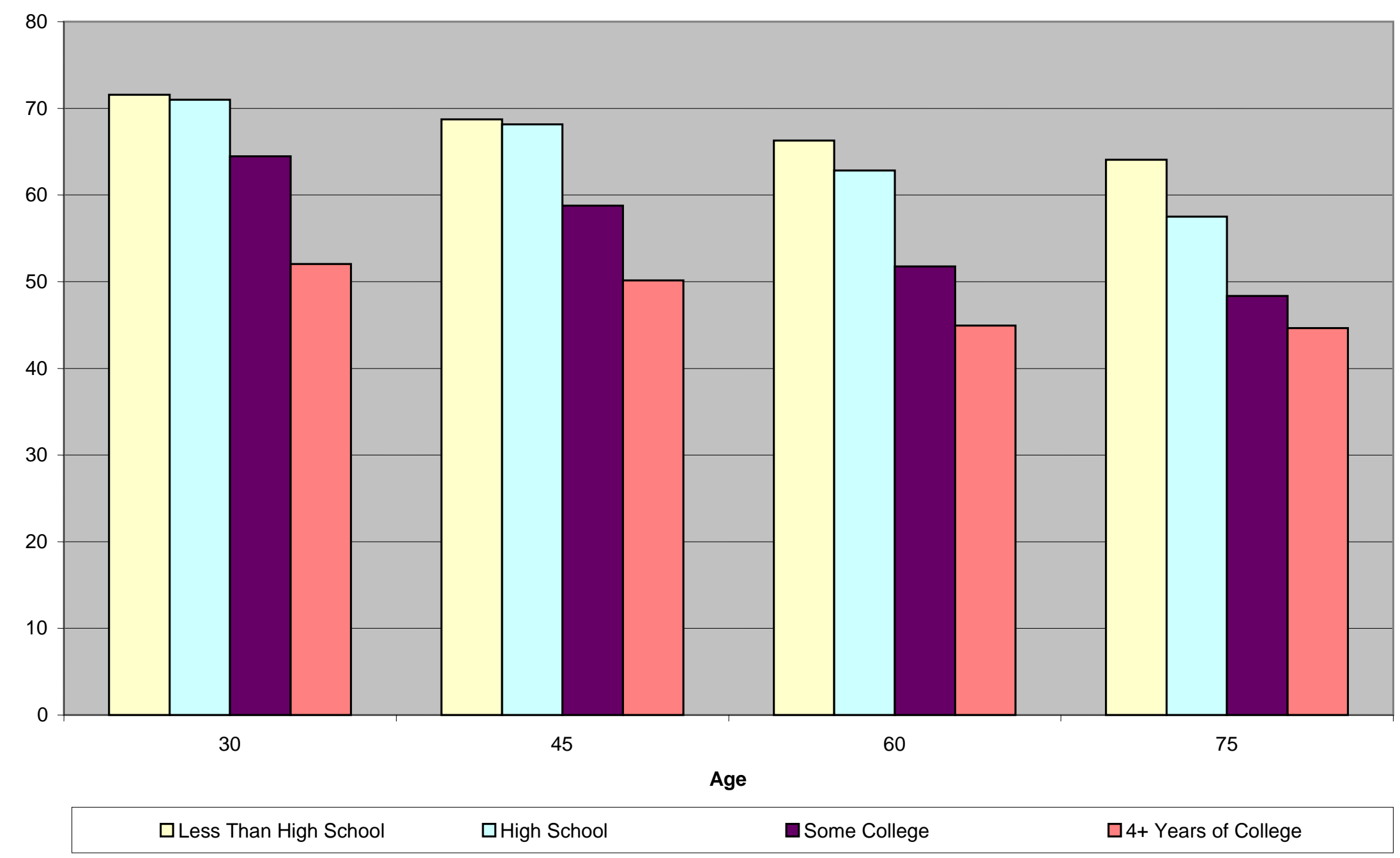




\begin{tabular}{llllll}
\hline \hline \multicolumn{2}{c}{$\begin{array}{l}\text { Low-Power } \\
\text { Couples }\end{array}$} & $\begin{array}{l}\text { Part-Power: } \\
\text { She has } \\
\text { College } \\
\text { Degree }\end{array}$ & $\begin{array}{l}\text { Part-Power: } \\
\text { He has } \\
\text { College } \\
\text { Degree }\end{array}$ & $\begin{array}{l}\text { Power } \\
\text { Couples }\end{array}$ & All \\
\hline Percentage of Couples from Same Birth State \\
64.1 & 56.8 & 54.0 & 45.9 & 59.2 \\
1990 & 62.8 & 54.8 & 52.5 & 45.1 & 58.9 \\
1980 & 64.2 & 55.8 & 53.1 & 47.9 & 61.1 \\
\hline Percentage of Sample & 62.4 & 8.5 & 12.3 & 16.8 & 100.0 \\
2000 & 69.3 & 6.2 & 12.0 & 12.5 & 100.0 \\
1990 & 75.6 & 4.1 & 11.2 & 9.1 & 100.0 \\
1980 & & & & \\
\hline \hline
\end{tabular}

U.S. Census (IPUMS) data. Sample includes all couples in which both spouses are aged 25 and older and born in the U.S.

Table 5: Couples in Birth State and Couples near Mother by Education

\begin{tabular}{|c|c|c|c|c|c|}
\hline & $\begin{array}{l}\text { Low-Power } \\
\text { Couples }\end{array}$ & $\begin{array}{l}\text { Part-Power: } \\
\text { She has } \\
\text { College } \\
\text { Degree }\end{array}$ & $\begin{array}{l}\text { Part-Power: } \\
\text { He has } \\
\text { College } \\
\text { Degree }\end{array}$ & $\begin{array}{l}\text { Power } \\
\text { Couples }\end{array}$ & All \\
\hline \multicolumn{6}{|l|}{2000 U.S. Census Data ${ }^{1}$} \\
\hline $\begin{array}{l}\text { Live in the birth state of } \\
\text { Neither }\end{array}$ & 22.6 & 26.1 & 36.2 & 40.1 & 27.5 \\
\hline Hers & 12.1 & 12.8 & 13.3 & 13.5 & 12.6 \\
\hline His & 11.9 & 14.4 & 11.8 & 13.9 & 12.4 \\
\hline Both & 53.3 & 46.7 & 38.7 & 32.5 & 47.5 \\
\hline \multicolumn{6}{|l|}{1990 U.S. Census Data ${ }^{1}$} \\
\hline \multicolumn{6}{|l|}{ Live in the birth state of } \\
\hline Neither & 22.8 & 26.1 & 36.9 & 40.2 & 26.9 \\
\hline Hers & 12.3 & 13.1 & 13.3 & 13.5 & 12.6 \\
\hline His & 11.9 & 14.9 & 11.8 & 14.1 & 12.3 \\
\hline Both & 53.1 & 46.0 & 38.0 & 32.2 & 48.2 \\
\hline \multicolumn{6}{|l|}{ 1992-1994 NSFH Data² } \\
\hline $\begin{array}{l}\text { Lives within } 30 \text { miles of } \\
\text { Neither mother }\end{array}$ & 18.9 & 25.5 & 35.8 & 49.4 & 29.3 \\
\hline Her mother & 17.4 & 23.2 & 13.6 & 15.9 & 16.9 \\
\hline His mother & 13.9 & 16.4 & 15.3 & 16.3 & 14.9 \\
\hline Both mothers & 49.9 & 34.8 & 35.3 & 18.4 & 38.9 \\
\hline
\end{tabular}


Table 6: Coresidence and Proximity

\begin{tabular}{|c|c|c|c|c|}
\hline & $\begin{array}{l}\text { (A) } \\
\text { Tobit }\end{array}$ & $\begin{array}{l}\text { (B) } \\
\text { Logit }\end{array}$ & $\begin{array}{r}(C \\
\text { Multir }\end{array}$ & Logit \\
\hline & $\begin{array}{l}\text { Distance from } \\
\text { Mother }\end{array}$ & $\begin{array}{l}\text { Live with or } \\
\text { near Mother }\end{array}$ & $\begin{array}{l}\text { Live near } \\
\text { Mother }\end{array}$ & $\begin{array}{l}\text { Live with } \\
\text { Mother }\end{array}$ \\
\hline $\begin{array}{l}\text { Total sample } \\
\text { Sample living with mom } \\
\text { Sample living near mom }\end{array}$ & \multicolumn{4}{|c|}{$\begin{array}{c}331 \\
3260 \\
\end{array}$} \\
\hline \multicolumn{5}{|l|}{ Adult Child Characteristics: } \\
\hline Female respondent & $\begin{array}{l}18.065 \\
(0.514)\end{array}$ & $\begin{array}{l}1.016 \\
(0.768)\end{array}$ & $\begin{array}{c}1.035 \\
(0.532)\end{array}$ & $\begin{array}{c}0.829 \\
(0.175)\end{array}$ \\
\hline Children less than 12 & $\begin{array}{l}19.151 \\
(0.544)\end{array}$ & $\begin{array}{c}1.051 \\
(0.429)\end{array}$ & $\begin{array}{c}1.084 \\
(0.202)\end{array}$ & $\begin{array}{c}0.638 * * * \\
(0.008)\end{array}$ \\
\hline Aged 25-34 & $\begin{array}{c}-121.577^{* * *} \\
(0.000)\end{array}$ & $\begin{array}{c}1.390 * * * \\
(0.000)\end{array}$ & $\begin{array}{c}1.340^{* * *} \\
(0.000)\end{array}$ & $\begin{array}{c}2.327^{* * * *} \\
(0.000)\end{array}$ \\
\hline Aged $45+$ & $\begin{array}{l}69.731^{*} \\
(0.083)\end{array}$ & $\begin{array}{c}0.768 * * * \\
(0.001)\end{array}$ & $\begin{array}{c}0.787 * * * \\
(0.003)\end{array}$ & $\begin{array}{c}0.580 * * * \\
(0.008)\end{array}$ \\
\hline College education & $\begin{array}{c}207.455^{* * *} \\
(0.000)\end{array}$ & $\begin{array}{c}0.475 * * * \\
(0.000)\end{array}$ & $\begin{array}{c}0.488 * * * \\
(0.000)\end{array}$ & $\begin{array}{c}0.318^{* * *} \\
(0.000)\end{array}$ \\
\hline Black & $\begin{array}{c}-106.067^{* *} \\
(0.013)\end{array}$ & $\begin{array}{c}1.475^{* * * *} \\
(0.000)\end{array}$ & $\begin{array}{l}1.484^{* * *} \\
(0.000)\end{array}$ & $\begin{array}{c}1.411^{* *} \\
(0.045)\end{array}$ \\
\hline Hispanic & $\begin{array}{c}166.735^{* * *} \\
(0.003)\end{array}$ & $\begin{array}{c}1.131 \\
(0.270)\end{array}$ & $\begin{array}{c}1.054 \\
(0.649)\end{array}$ & $\begin{array}{c}1.981^{* * *} \\
(0.002)\end{array}$ \\
\hline Divorced/Widowed/Separated & $\begin{array}{c}118.474^{* *} \\
(0.037)\end{array}$ & $\begin{array}{c}0.904 \\
(0.376)\end{array}$ & $\begin{array}{l}1.056 \\
(0.648)\end{array}$ & $\begin{array}{c}0.612^{* * *} \\
(0.008)\end{array}$ \\
\hline Married & $\begin{array}{c}198.944 * * * \\
(0.000)\end{array}$ & $\begin{array}{c}0.708 * * * \\
(0.001)\end{array}$ & $\begin{array}{c}0.954 \\
(0.653)\end{array}$ & $\begin{array}{c}0.094 * * * \\
(0.000)\end{array}$ \\
\hline Only child & $\begin{array}{c}-198.697 * * * \\
(0.003)\end{array}$ & $\begin{array}{c}1.617 * * * \\
(0.000)\end{array}$ & $\begin{array}{c}1.507 * * * \\
(0.003)\end{array}$ & $\begin{array}{c}3.606^{* * * *} \\
(0.000)\end{array}$ \\
\hline $\begin{array}{l}\text { First-born child } \\
\text { Mother Characteristics }\end{array}$ & $\begin{array}{l}-35.565 \\
(0.295)\end{array}$ & $\begin{array}{l}1.116 \\
(0.103)\end{array}$ & $\begin{array}{l}1.142^{*} \\
(0.052)\end{array}$ & $\begin{array}{c}0.877 \\
(0.474)\end{array}$ \\
\hline College degree & $\begin{array}{l}41.662 \\
(0.221)\end{array}$ & $\begin{array}{c}0.761 * * * \\
(0.000)\end{array}$ & $\begin{array}{c}0.759 * * * \\
(0.000)\end{array}$ & $\begin{array}{c}0.786 \\
(0.158)\end{array}$ \\
\hline Poor health & $\begin{array}{l}33.415 \\
(0.393)\end{array}$ & $\begin{array}{c}0.909 \\
(0.219)\end{array}$ & $\begin{array}{c}0.939 \\
(0.419)\end{array}$ & $\begin{array}{c}0.620 * * \\
(0.020)\end{array}$ \\
\hline Unmarried & $\begin{array}{c}-98.532^{* * *} \\
(0.001)\end{array}$ & $\begin{array}{c}1.280 * * * \\
(0.000)\end{array}$ & $\begin{array}{l}1.165^{* *} \\
(0.010)\end{array}$ & $\begin{array}{c}3.993^{* * *} \\
(0.000)\end{array}$ \\
\hline Aged 75 and older & $\begin{array}{l}16.488 \\
(0.637) \\
\end{array}$ & $\begin{array}{c}1.004 \\
(0.957)\end{array}$ & $\begin{array}{c}0.968 \\
(0.643) \\
\end{array}$ & $\begin{array}{c}1.569 * * * \\
(0.004)\end{array}$ \\
\hline LR Chi2 & 380.1 & 525.44 & & \\
\hline Prob>chi2 & 0 & 0 & & \\
\hline Log likelihood & -49835.1 & -3999.7 & & \\
\hline Pseudo R2 & 0.0038 & 0.0616 & & \\
\hline
\end{tabular}

NSFH Sample Wave 2. Includes all partnered and non-partnered adult children aged 25 and older.

Coefficients in column (B) are presented as odds ratios, coefficients in column (C) are presented as relative risk ratios. P-values are in parentheses. Other control variables included are Region (South, Midwest, West, East (base case)), MSA indicator, average commute time in MSA or county, and relationship variables (Good, Poor, Average (base)). 
Table 7a: Determinants of Coresidence and Proximity, SMNLogit - Unmarried Sample

\begin{tabular}{|c|c|c|c|c|c|c|}
\hline & \multicolumn{2}{|c|}{ All Unmarried } & \multicolumn{2}{|c|}{ Unmarried Women } & \multicolumn{2}{|c|}{ Unmarried Men } \\
\hline & $\begin{array}{l}\text { Near } \\
\text { Mother }\end{array}$ & $\begin{array}{l}\text { With } \\
\text { Mother }\end{array}$ & $\begin{array}{l}\text { Near } \\
\text { Mother }\end{array}$ & $\begin{array}{c}\text { With } \\
\text { Mother }\end{array}$ & $\begin{array}{l}\text { Near } \\
\text { Mother }\end{array}$ & $\begin{array}{c}\text { With } \\
\text { Mother }\end{array}$ \\
\hline $\begin{array}{l}\text { Adult Child Characteristics: } \\
\text { Female respondent }\end{array}$ & $\begin{array}{c}1.08 \\
(0.55)\end{array}$ & $\begin{array}{c}0.70 * * \\
(0.05)\end{array}$ & & & & \\
\hline Children less than 12 & $\begin{array}{l}1.13 \\
(0.41)\end{array}$ & $\begin{array}{c}0.58 * * \\
(0.02)\end{array}$ & $\begin{array}{l}1.18 \\
(0.32)\end{array}$ & $\begin{array}{l}0.61^{*} \\
(0.07)\end{array}$ & $\begin{array}{l}1.12 \\
(0.79)\end{array}$ & $\begin{array}{l}1.15 \\
(0.81)\end{array}$ \\
\hline Aged 25-34 & $\begin{array}{l}1.35 * * \\
(0.04)\end{array}$ & $\begin{array}{c}2.72 * * \\
(0.00)\end{array}$ & $\begin{array}{l}1.39 * \\
(0.06)\end{array}$ & $\begin{array}{c}2.75^{* * * *} \\
(0.00)\end{array}$ & $\begin{array}{l}1.24 \\
(0.39)\end{array}$ & $\begin{array}{c}2.72^{* * *} \\
(0.00)\end{array}$ \\
\hline Aged $45+$ & $\begin{array}{l}0.71 * * \\
(0.04)\end{array}$ & $\begin{array}{l}0.61^{*} \\
(0.06)\end{array}$ & $\begin{array}{c}0.81 \\
(0.29)\end{array}$ & $\begin{array}{c}0.59 \\
(0.12)\end{array}$ & $\begin{array}{l}0.53^{* *} \\
(0.04)\end{array}$ & $\begin{array}{c}0.62 \\
(0.27)\end{array}$ \\
\hline College education & $\begin{array}{c}0.46^{* * *} \\
(0.00)\end{array}$ & $\begin{array}{c}0.24 * * * \\
(0.00)\end{array}$ & $\begin{array}{c}0.50 * * * \\
(0.00)\end{array}$ & $\begin{array}{c}0.25^{* * * *} \\
(0.00)\end{array}$ & $\begin{array}{c}0.38 * * * \\
(0.00)\end{array}$ & $\begin{array}{c}0.21^{* * *} \\
(0.00)\end{array}$ \\
\hline Black & $\begin{array}{c}1.57 * * * \\
(0.00)\end{array}$ & $\begin{array}{l}1.34 \\
(0.16)\end{array}$ & $\begin{array}{c}1.83^{* * * *} \\
(0.00)\end{array}$ & $\begin{array}{l}1.01 \\
(0.97)\end{array}$ & $\begin{array}{l}1.05 \\
(0.85)\end{array}$ & $\begin{array}{l}1.71^{*} \\
(0.10)\end{array}$ \\
\hline Hispanic & $\begin{array}{l}1.00 \\
(1.00)\end{array}$ & $\begin{array}{l}1.94 * * \\
(0.02)\end{array}$ & $\begin{array}{l}1.02 \\
(0.94)\end{array}$ & $\begin{array}{l}1.70 \\
(0.15)\end{array}$ & $\begin{array}{c}0.97 \\
(0.93)\end{array}$ & $\begin{array}{l}2.50^{*} \\
(0.06)\end{array}$ \\
\hline Divorced/Widowed/Separated & $\begin{array}{c}1.01 \\
(0.92)\end{array}$ & $\begin{array}{c}0.64 * * \\
(0.02)\end{array}$ & $\begin{array}{c}1.00 \\
(1.00)\end{array}$ & $\begin{array}{l}0.49 * * \\
(0.01)\end{array}$ & $\begin{array}{c}1.14 \\
(0.58)\end{array}$ & $\begin{array}{c}0.77 \\
(0.41)\end{array}$ \\
\hline Only child & $\begin{array}{l}1.82^{*} \\
(0.06)\end{array}$ & $\begin{array}{c}4.19 * * * \\
(0.00)\end{array}$ & $\begin{array}{l}2.21^{*} \\
(0.05)\end{array}$ & $\begin{array}{c}5.15^{* * * *} \\
(0.00)\end{array}$ & $\begin{array}{l}1.48 \\
(0.50)\end{array}$ & $\begin{array}{l}3.94 * * \\
(0.04)\end{array}$ \\
\hline First-born child & $\begin{array}{l}1.26^{*} \\
(0.09)\end{array}$ & $\begin{array}{c}1.03 \\
(0.90)\end{array}$ & $\begin{array}{l}1.49 * * \\
(0.02)\end{array}$ & $\begin{array}{c}1.17 \\
(0.60)\end{array}$ & $\begin{array}{c}0.89 \\
(0.65)\end{array}$ & $\begin{array}{c}0.78 \\
(0.50)\end{array}$ \\
\hline \multicolumn{7}{|l|}{ Mother Characteristics } \\
\hline College degree & $\begin{array}{c}0.71 * * \\
(0.01)\end{array}$ & $\begin{array}{l}0.69 * \\
(0.08)\end{array}$ & $\begin{array}{c}0.70^{* *} \\
(0.03)\end{array}$ & $\begin{array}{c}0.66 \\
(0.14)\end{array}$ & $\begin{array}{c}0.71 \\
(0.16)\end{array}$ & $\begin{array}{c}0.72 \\
(0.32)\end{array}$ \\
\hline Poor health & $\begin{array}{c}1.03 \\
(0.86)\end{array}$ & $\begin{array}{l}0.63^{*} \\
(0.08)\end{array}$ & $\begin{array}{l}1.09 \\
(0.64)\end{array}$ & $\begin{array}{c}0.85 \\
(0.59)\end{array}$ & $\begin{array}{c}0.90 \\
(0.72)\end{array}$ & $\begin{array}{c}0.28^{* * *} \\
(0.01)\end{array}$ \\
\hline Unmarried & $\begin{array}{l}1.25^{*} \\
(0.06)\end{array}$ & $\begin{array}{c}3.22 * * * \\
(0.00)\end{array}$ & $\begin{array}{l}1.33^{*} \\
(0.05)\end{array}$ & $\begin{array}{c}3.06^{* * *} \\
(0.00)\end{array}$ & $\begin{array}{c}1.15 \\
(0.53)\end{array}$ & $\begin{array}{c}3.52^{* * * *} \\
(0.00)\end{array}$ \\
\hline Aged 75 and older & $\begin{array}{c}1.02 \\
(0.90)\end{array}$ & $\begin{array}{c}1.35 \\
(0.14)\end{array}$ & $\begin{array}{c}0.92 \\
(0.62)\end{array}$ & $\begin{array}{l}1.68^{*} \\
(0.04)\end{array}$ & $\begin{array}{l}1.25 \\
(0.38)\end{array}$ & $\begin{array}{c}0.97 \\
(0.94)\end{array}$ \\
\hline Poor relationship with mother & $\begin{array}{c}0.81 \\
(0.21)\end{array}$ & $\begin{array}{c}0.51^{* *} \\
(0.02)\end{array}$ & $\begin{array}{c}0.85 \\
(0.43)\end{array}$ & $\begin{array}{c}0.55 \\
(0.12)\end{array}$ & $\begin{array}{c}0.70 \\
(0.30)\end{array}$ & $\begin{array}{c}0.44 \\
(0.10)\end{array}$ \\
\hline Good relationship with mother & $\begin{array}{c}0.96 \\
(0.71) \\
\end{array}$ & $\begin{array}{c}0.96 \\
(0.79) \\
\end{array}$ & $\begin{array}{r}0.97 \\
(0.85) \\
\end{array}$ & $\begin{array}{c}0.97 \\
(0.91) \\
\end{array}$ & $\begin{array}{c}0.90 \\
(0.61) \\
\end{array}$ & $\begin{array}{c}0.93 \\
(0.78) \\
\end{array}$ \\
\hline Sample & \multicolumn{2}{|c|}{1733} & \multicolumn{2}{|c|}{1138} & \multicolumn{2}{|c|}{595} \\
\hline Sample living with mother & \multicolumn{2}{|c|}{851} & \multicolumn{2}{|c|}{592} & \multicolumn{2}{|c|}{259} \\
\hline Sample living near mother & \multicolumn{2}{|c|}{257} & \multicolumn{2}{|c|}{136} & \multicolumn{2}{|c|}{121} \\
\hline LR Chi2 & \multicolumn{2}{|c|}{322.65} & \multicolumn{2}{|c|}{187.73} & \multicolumn{2}{|c|}{152.55} \\
\hline Prob>chi2 & \multicolumn{2}{|c|}{0} & & & & \\
\hline Log likelihood & -15 & & & & & \\
\hline Pseudo R2 & & & & & & \\
\hline
\end{tabular}

NSFH Sample Wave 2. Includes all non-partnered adult children aged 25 and older. Coefficients are presented as relative risk ratios. P-values are in parentheses. Other control variables included are Region (South, Midwest, West, East (base case)), MSA indicator and average commute time in MSA or county. 
Table 7b: Determinants of Coresidence and Proximity, SMNLogit - Married Sample

\begin{tabular}{|c|c|c|c|c|c|c|}
\hline & \multicolumn{2}{|c|}{ All Married } & \multicolumn{2}{|c|}{ Married Women } & \multicolumn{2}{|c|}{ Married Men } \\
\hline & $\begin{array}{c}\text { Near } \\
\text { Mother }\end{array}$ & $\begin{array}{c}\text { With } \\
\text { Mother }\end{array}$ & $\begin{array}{c}\text { Near } \\
\text { Mother }\end{array}$ & $\begin{array}{l}\text { With } \\
\text { Mother }\end{array}$ & $\begin{array}{c}\text { Near } \\
\text { Mother }\end{array}$ & $\begin{array}{c}\text { With } \\
\text { Mother }\end{array}$ \\
\hline \multicolumn{7}{|l|}{ Adult Child Characteristics: } \\
\hline Female respondent & $\begin{array}{c}1.01 \\
(0.82)\end{array}$ & $\begin{array}{l}1.78 * * \\
(0.03)\end{array}$ & & & & \\
\hline Children less than 12 & $\begin{array}{l}1.06 \\
(0.44)\end{array}$ & $\begin{array}{l}1.12 \\
(0.71)\end{array}$ & $\begin{array}{c}1.01 \\
(0.95)\end{array}$ & $\begin{array}{c}0.93 \\
(0.85)\end{array}$ & $\begin{array}{l}1.10 \\
(0.37)\end{array}$ & $\begin{array}{c}1.15 \\
(0.77)\end{array}$ \\
\hline Aged 25-34 & $\begin{array}{c}1.35^{* * *} \\
(0.00)\end{array}$ & $\begin{array}{c}1.31 \\
(0.38)\end{array}$ & $\begin{array}{c}1.37 * * * \\
(0.00)\end{array}$ & $\begin{array}{c}1.41 \\
(0.36)\end{array}$ & $\begin{array}{l}1.37 * * \\
(0.01)\end{array}$ & $\begin{array}{c}1.22 \\
(0.72)\end{array}$ \\
\hline Aged $45+$ & $\begin{array}{c}0.80 * * \\
(0.02)\end{array}$ & $\begin{array}{c}0.59 \\
(0.13)\end{array}$ & $\begin{array}{c}0.70 * * \\
(0.01)\end{array}$ & $\begin{array}{c}0.34^{* *} \\
(0.02)\end{array}$ & $\begin{array}{c}0.96 \\
(0.76)\end{array}$ & $\begin{array}{c}1.42 \\
(0.53)\end{array}$ \\
\hline College education & $\begin{array}{c}0.50^{* * *} \\
(0.00)\end{array}$ & $\begin{array}{l}0.50 * * \\
(0.03)\end{array}$ & $\begin{array}{c}0.52 * * * \\
(0.00)\end{array}$ & $\begin{array}{c}0.70 \\
(0.36)\end{array}$ & $\begin{array}{c}0.47 * * * \\
(0.00)\end{array}$ & $\begin{array}{c}0.25^{* *} \\
(0.02)\end{array}$ \\
\hline Black & $\begin{array}{c}1.41^{* * *} \\
(0.00)\end{array}$ & $\begin{array}{c}2.41 * * * \\
(0.01)\end{array}$ & $\begin{array}{l}1.51^{* *} \\
(0.01)\end{array}$ & $\begin{array}{c}3.40^{* * *} \\
(0.00)\end{array}$ & $\begin{array}{c}1.27 \\
(0.16)\end{array}$ & $\begin{array}{c}1.02 \\
(0.98)\end{array}$ \\
\hline Hispanic & $\begin{array}{l}1.07 \\
(0.59)\end{array}$ & $\begin{array}{c}2.34 * * \\
(0.03)\end{array}$ & $\begin{array}{c}0.95 \\
(0.78)\end{array}$ & $\begin{array}{l}3.16^{* *} \\
(0.02)\end{array}$ & $\begin{array}{c}1.23 \\
(0.29)\end{array}$ & $\begin{array}{c}1.01 \\
(0.99)\end{array}$ \\
\hline Only child & $\begin{array}{c}1.44^{* *} \\
(0.02)\end{array}$ & $\begin{array}{l}2.93 * * \\
(0.01)\end{array}$ & $\begin{array}{l}1.83^{* * *} \\
(0.01)\end{array}$ & $\begin{array}{l}3.94 * * \\
(0.01)\end{array}$ & $\begin{array}{l}1.18 \\
(0.46)\end{array}$ & $\begin{array}{c}2.41 \\
(0.19)\end{array}$ \\
\hline First-born child & $\begin{array}{c}1.11 \\
(0.19)\end{array}$ & $\begin{array}{c}0.55 \\
(0.11)\end{array}$ & $\begin{array}{c}1.06 \\
(0.58)\end{array}$ & $\begin{array}{c}0.47 \\
(0.13)\end{array}$ & $\begin{array}{c}1.18 \\
(0.18)\end{array}$ & $\begin{array}{c}0.78 \\
(0.67)\end{array}$ \\
\hline \multicolumn{7}{|l|}{ Mother Characteristics } \\
\hline College degree & $\begin{array}{c}0.78^{* * *} \\
(0.00)\end{array}$ & $\begin{array}{l}1.03 \\
(0.94)\end{array}$ & $\begin{array}{c}0.71^{* * *} \\
(0.00)\end{array}$ & $\begin{array}{c}0.90 \\
(0.80)\end{array}$ & $\begin{array}{c}0.87 \\
(0.25)\end{array}$ & $\begin{array}{c}1.26 \\
(0.65)\end{array}$ \\
\hline Poor health & $\begin{array}{c}0.91 \\
(0.31)\end{array}$ & $\begin{array}{c}0.63 \\
(0.20)\end{array}$ & $\begin{array}{c}0.98 \\
(0.87)\end{array}$ & $\begin{array}{c}0.44 \\
(0.10)\end{array}$ & $\begin{array}{c}0.83 \\
(0.20)\end{array}$ & $\begin{array}{c}1.20 \\
(0.73)\end{array}$ \\
\hline Unmarried & $\begin{array}{l}1.14^{*} \\
(0.06)\end{array}$ & $\begin{array}{c}9.33^{* * *} \\
(0.00)\end{array}$ & $\begin{array}{c}1.10 \\
(0.29)\end{array}$ & $\begin{array}{c}11.76^{* * *} \\
(0.00)\end{array}$ & $\begin{array}{l}1.20^{*} \\
(0.08)\end{array}$ & $\begin{array}{c}6.36 * * * \\
(0.00)\end{array}$ \\
\hline Aged 75 and older & $\begin{array}{c}0.95 \\
(0.52)\end{array}$ & $\begin{array}{c}2.43^{* * * *} \\
(0.00)\end{array}$ & $\begin{array}{c}1.11 \\
(0.34)\end{array}$ & $\begin{array}{c}3.45^{* * *} \\
(0.00)\end{array}$ & $\begin{array}{l}0.78^{*} \\
(0.05)\end{array}$ & $\begin{array}{c}1.13 \\
(0.82)\end{array}$ \\
\hline Poor relationship with mother & $\begin{array}{c}0.85 \\
(0.14)\end{array}$ & $\begin{array}{c}0.53 \\
(0.18)\end{array}$ & $\begin{array}{l}0.79^{*} \\
(0.10)\end{array}$ & $\begin{array}{c}0.67 \\
(0.45)\end{array}$ & $\begin{array}{c}0.91 \\
(0.56)\end{array}$ & $\begin{array}{c}0.24 \\
(0.18)\end{array}$ \\
\hline Good relationship with mother & $\begin{array}{c}1.10 \\
(0.14) \\
\end{array}$ & $\begin{array}{c}0.85 \\
(0.52) \\
\end{array}$ & $\begin{array}{c}1.04 \\
(0.70) \\
\end{array}$ & $\begin{array}{c}0.76 \\
(0.41) \\
\end{array}$ & $\begin{array}{l}1.20^{*} \\
(0.07)\end{array}$ & $\begin{array}{c}1.03 \\
(0.95) \\
\end{array}$ \\
\hline Sample & \multicolumn{2}{|c|}{4517} & \multicolumn{2}{|c|}{2530} & \multicolumn{2}{|c|}{1987} \\
\hline Sample living with mother & \multicolumn{2}{|c|}{2,409} & \multicolumn{2}{|c|}{1,364} & \multicolumn{2}{|c|}{1,045} \\
\hline Sample living near mother & \multicolumn{2}{|c|}{74} & \multicolumn{2}{|c|}{49} & \multicolumn{2}{|c|}{25} \\
\hline LR Chi2 & & & & & & \\
\hline Prob>chi2 & & & & & & \\
\hline Log likelihood & -32 & & & .27 & & \\
\hline Pseudo R2 & & & & & & \\
\hline
\end{tabular}

NSFH Sample Wave 2. Includes all married (and partnered) adult children aged 25 and older. Coefficients are presented as relative risk ratios. P-values are in parentheses. Other control variables included are Region (South, Midwest, West, East (base case)), MSA indicator and, average commute time in MSA. 
Table 8: Determinants of Coresidence and Proximity, MNLogit Married Sample, Both Mothers ALUS

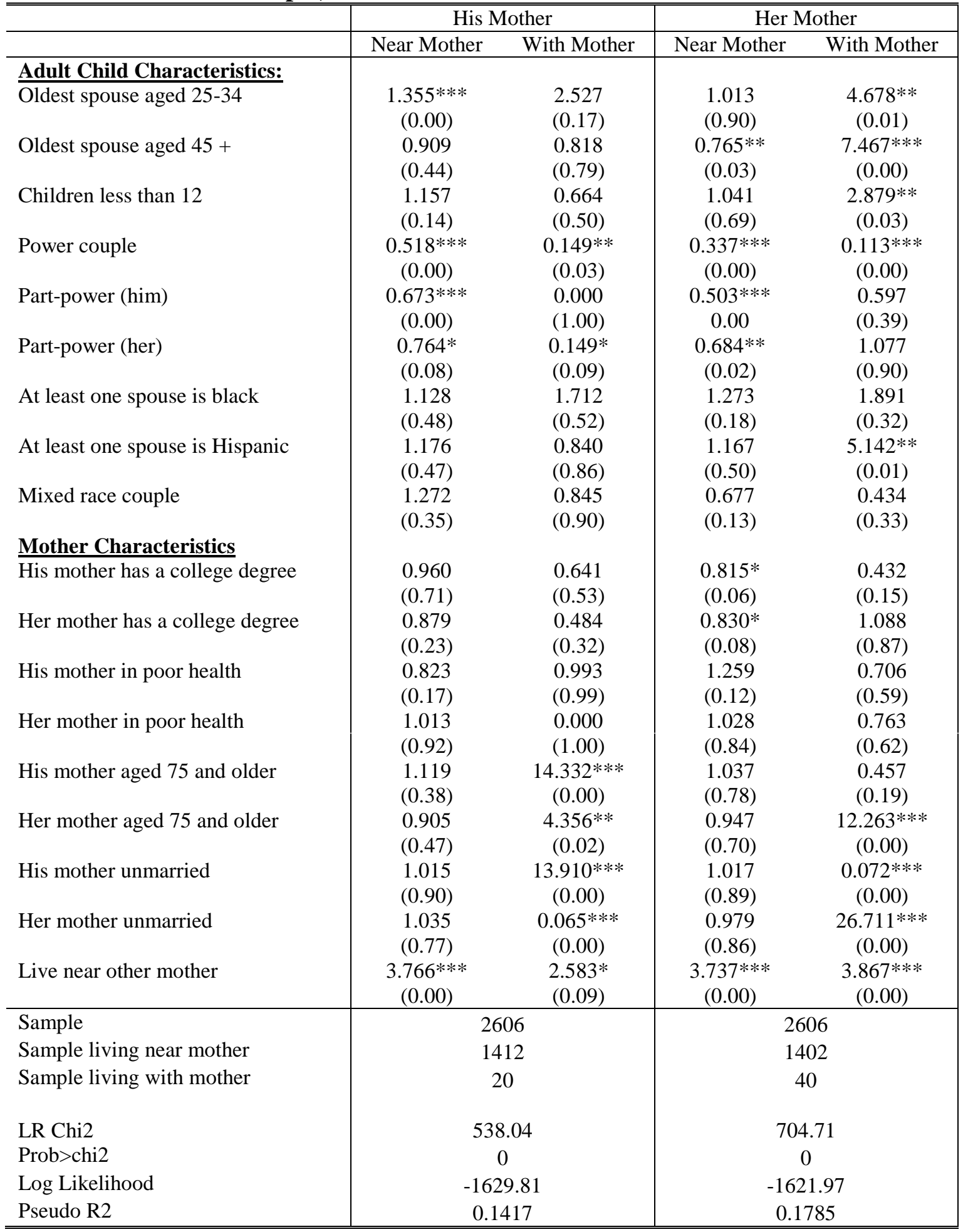

NSFH Sample Wave 2. Includes all married (and partnered) adult children aged 25 and older. Coefficients are presented as relative risk ratios. P-values are in parentheses. Other control variables included are only child and first-born child status for both spouses, Region (South, Midwest, West, East (base case)), MSA indicator, average commute time in MSA or county, relationship variables (Good, Poor, Average (base)). 
Appendix 1: Summary of Selected Proximity Literature

\begin{tabular}{|c|c|c|c|c|c|}
\hline & Survey; Unit of Analysis & $\begin{array}{l}\text { Distance } \\
\text { Variable }\end{array}$ & $\begin{array}{l}\text { Primary } \\
\text { Analysis }\end{array}$ & $\begin{array}{l}\text { Regression } \\
\text { Technique }\end{array}$ & Results \\
\hline Clark and Wolf (1992) & $\begin{array}{l}\text { National Survey of Families } \\
\text { and Households (NSFH) Wave } \\
1 \text { (1987); Parent, parent-child } \\
\text { pairs. }\end{array}$ & $\begin{array}{l}\text { Grouped } \\
\text { Distance(co- } \\
\text { residence } \\
\text { combined with less } \\
\text { than or equal to } 10 \\
\text { miles to define } \\
\text { "Near") }\end{array}$ & $\begin{array}{l}\text { Probability that } \\
\text { elderly respondent } \\
\text { has at least one } \\
\text { child near; } \\
\text { Probability that } \\
\text { child (for each } \\
\text { parent-child pair) } \\
\text { lives near } \\
\text { respondent. }\end{array}$ & $\begin{array}{l}\text { Logistic } \\
\text { Regressions }\end{array}$ & $\begin{array}{l}\text { Older parents with more } \\
\text { resources (youth, more } \\
\text { education, living spouse) are } \\
\text { less likely to have a child } \\
\text { living within } 10 \text { miles. } \\
\text { Elderly more likely to live } \\
\text { near a child who has } \\
\text { children than one who does } \\
\text { not. }\end{array}$ \\
\hline $\begin{array}{l}\text { Glaser and Tomassini } \\
(2000)\end{array}$ & $\begin{array}{l}\text { British Retirement Survey } \\
\text { (1994) and the Italian } \\
\text { Indagine Multipscopo sulle } \\
\text { Famiglie (1995); Mothers }\end{array}$ & $\begin{array}{l}\text { Grouped Distance } \\
\text { (coresidence, less } \\
\text { than } 10 \text { miles, } \\
\text { greater than } 10 \\
\text { miles) }\end{array}$ & $\begin{array}{l}\text { Mothers Proximity } \\
\text { to her closest child; }\end{array}$ & Multinomial logit & $\begin{array}{l}\text { Proximity in Britain more } \\
\text { likely to arise from the } \\
\text { needs of the older } \\
\text { generation; In Italy, } \\
\text { proximity may be more } \\
\text { linked to culture than need. }\end{array}$ \\
\hline Konrad et al (2002) & $\begin{array}{l}\text { German Aging Survey (1996) } \\
\text { Children of Respondent, } \\
\text { respondents with one or two } \\
\text { living children. }\end{array}$ & $\begin{array}{l}\text { Grouped } \\
\text { descriptive } \\
\text { distances }^{29}\end{array}$ & $\begin{array}{l}\text { Distance between } \\
\text { each sibling or only } \\
\text { child and mother. }\end{array}$ & $\begin{array}{l}\text { Ordinal logistic } \\
\text { model }\end{array}$ & $\begin{array}{l}\text { Elder siblings live farther } \\
\text { than only siblings. }\end{array}$ \\
\hline Lin and Rogerson (1995) & $\begin{array}{l}\text { National Survey of Families } \\
\text { and Households (NSFH) Wave } \\
1 \text { (1987); Parent }\end{array}$ & $\begin{array}{l}\text { Natural logarithm } \\
\text { of distances (miles) } \\
\text { to closest and } \\
\text { second closest } \\
\text { child; excludes co- } \\
\text { residents. }\end{array}$ & $\begin{array}{l}\text { Factors affecting } \\
\text { distance to closest } \\
\text { child and second } \\
\text { closest child. }\end{array}$ & $\begin{array}{l}\text { OLG, truncated } \\
\text { OLG for distance } \\
\text { to second closest } \\
\text { child. }\end{array}$ & $\begin{array}{l}\text { Health and disability of } \\
\text { parent have little effect on } \\
\text { proximity; gender is not a } \\
\text { factor, except for widowed } \\
\text { mothers; older children live } \\
\text { farther away. }\end{array}$ \\
\hline
\end{tabular}

\footnotetext{
${ }^{29}$ The grouped distances in Konrad et al (2002) are coresidence, in the neighborhood, in the same urban community, in a different community, but less than two hours travel time away, further away.
} 
Appendix 1: Summary of Selected Proximity Literature

\begin{tabular}{|c|c|c|c|c|c|}
\hline & Survey; Unit of Analysis & $\begin{array}{l}\text { Distance } \\
\text { Variable }\end{array}$ & $\begin{array}{l}\text { Primary } \\
\text { Analysis }\end{array}$ & $\begin{array}{l}\text { Regression } \\
\text { Technique }\end{array}$ & Results \\
\hline $\begin{array}{l}\text { Rainer and Siedler } \\
\text { (Forthcoming) }\end{array}$ & $\begin{array}{l}\text { German Socio-Economic } \\
\text { Panel Study (GSOEP); } \\
\text { families; children from one } \\
\text { and two-child families and } \\
\text { their parents. } \\
\text { National Survey of Families } \\
\text { and Households (NSFH) Wave } \\
1 \text { (1987); adult children. }\end{array}$ & $\begin{array}{l}\text { Grouped } \\
\text { descriptive } \\
\text { distances } \\
\text { (GSOEP) }^{30} \\
\text { Distance in Miles } \\
\text { (NSFH) }\end{array}$ & $\begin{array}{l}\text { Determinants of } \\
\text { Child-Parent } \\
\text { Geographic } \\
\text { Distance. Focus on } \\
\text { differences } \\
\text { between siblings } \\
\text { and only children. }\end{array}$ & $\begin{array}{l}\text { Ordered Probit } \\
\text { (GSOEP); Tobit } \\
\text { (NSFH) }\end{array}$ & $\begin{array}{l}\text { Children with siblings live } \\
\text { farther away than only } \\
\text { children. Impact seen only } \\
\text { for areas of high } \\
\text { unemployment. }\end{array}$ \\
\hline $\begin{array}{l}\text { Rogerson Weng and Lin } \\
\text { (1993) }\end{array}$ & $\begin{array}{l}\text { National Survey of Families } \\
\text { and Households (NSFH) Wave } \\
1 \text { (1987); Children } 16 \text { years of } \\
\text { age and older. }\end{array}$ & $\begin{array}{l}\text { Natural logarithm } \\
\text { of distance } \\
\text { (miles). Co- } \\
\text { residence excluded. }\end{array}$ & $\begin{array}{l}\text { Distance between } \\
\text { children and } \\
\text { parents; separates } \\
\text { parents by living } \\
\text { arrangements }^{31} \text {. }\end{array}$ & OLS & $\begin{array}{l}\text { Proximity most related to } \\
\text { region, mobility history, } \\
\text { education and age. Less } \\
\text { important are siblings and } \\
\text { living arrangement of } \\
\text { parents. }\end{array}$ \\
\hline $\begin{array}{l}\text { Rogerson, Burr and Lin } \\
\text { (1997) }\end{array}$ & $\begin{array}{l}\text { National Survey of Families } \\
\text { and Households (NSFH) } \\
\text { Waves } 1 \text { and } 2 \text { (1987, 1993); } \\
\text { Parents (aged } 60 \text { and over) }\end{array}$ & $\begin{array}{l}\text { Distance in miles } \\
\text { (top-coded at } 300 \\
\text { miles); }\end{array}$ & $\begin{array}{l}\text { Changes in } \\
\text { proximity between } \\
\text { respondent and } \\
\text { their closest child } \\
\text { (not necessarily the } \\
\text { same child in both } \\
\text { waves) }\end{array}$ & $\begin{array}{l}\text { Multinomial Logit } \\
\text { (Convergence, } \\
\text { Divergence, No } \\
\text { Change); } \\
\text { Convergence then } \\
\text { modeled separately } \\
\text { as living } \\
\text { independently and } \\
\text { living dependently. }\end{array}$ & $\begin{array}{l}\text { Convergence is positively } \\
\text { related to an increase in } \\
\text { parents' need for care. } \\
\text { Widowhood increases } \\
\text { likelihood of coresidence } \\
\text { but not convergence without } \\
\text { coresidence. }\end{array}$ \\
\hline
\end{tabular}

\footnotetext{
${ }^{30}$ Rainer and Siedler grouped distances for the GSOEP: whether the child lives (a) in the same household, house or neighbourhood; (b) in the same town, but more than 15 minutes walk away ; (c) in a different town, but less than one hour of travel time away; and (d) further away.

${ }^{31}$ Rogerson, Weng and Lin (1993) analyze separately the distance to mother and father, based on their living arrangements - parents alive and living apart, mother only alive, father only alive and both parents alive and living together.
} 
Appendix 1: Summary of Selected Proximity Literature

\begin{tabular}{|c|c|c|c|c|c|}
\hline & Survey; Unit of Analysis & $\begin{array}{l}\text { Distance } \\
\text { Variable }\end{array}$ & $\begin{array}{l}\text { Primary } \\
\text { Analysis }\end{array}$ & $\begin{array}{l}\text { Regression } \\
\text { Technique }\end{array}$ & Results \\
\hline Silverstein (1995) & $\begin{array}{l}\text { Longitudinal Study on Aging } \\
\text { (LSOA) 1984, 1988; parents } \\
\text { (aged } 70 \text { and over) with at } \\
\text { least one surviving child. }\end{array}$ & $\begin{array}{l}\text { Time: How quickly } \\
\text { can the nearest } \\
\text { child get to your } \\
\text { house/apartment } \\
\text { Natural logarithm } \\
\text { of time in minutes. } \\
\text { Coresidents } \\
\text { included as } 0 \\
\text { minutes. }\end{array}$ & $\begin{array}{l}\text { Determinants of } \\
\text { temporal } \\
\text { convergence and } \\
\text { divergence }\end{array}$ & $\begin{array}{l}\text { Two-stage model: } \\
\text { logistic regression } \\
\text { to predict whether } \\
\text { convergence } \\
\text { occurs, and OLS } \\
\text { (or Tobit) to } \\
\text { predict size of } \\
\text { convergence. } \\
\text { Similarly for } \\
\text { divergence, size of } \\
\text { divergence. }\end{array}$ & $\begin{array}{l}\text { Marital status of parents } \\
\text { increases only the size of } \\
\text { the convergence, not the } \\
\text { likelihood that it will occur. } \\
\text { Unmarried elders also tend } \\
\text { to diverge farthest from } \\
\text { their children. }\end{array}$ \\
\hline $\begin{array}{l}\text { Shelton and Grundy } \\
\text { (2000) }\end{array}$ & $\begin{array}{l}\text { British Social Attitudes Survey } \\
\text { (BSAS) 1986, 1995; Adult } \\
\text { children aged 18-54.. }\end{array}$ & $\begin{array}{l}\text { Time: About how } \\
\text { long does it usually } \\
\text { take to get door to } \\
\text { door. Categories: } \\
\text { up to half an hour } \\
\text { (includes } \\
\text { coresidents), } \\
\text { between half an } \\
\text { hour and an hour, } \\
\text { and an hour or } \\
\text { more. }\end{array}$ & $\begin{array}{l}\text { Changes in co- } \\
\text { residence patterns } \\
\text { and characteristics } \\
\text { associated with } \\
\text { variations in } \\
\text { proximity. }\end{array}$ & $\begin{array}{l}\text { (1) Multinomial } \\
\text { logit on three } \\
\text { categories. } \\
\text { Proximity to } \\
\text { mother and father } \\
\text { modeled } \\
\text { separately; (2) } \\
\text { excludes coresident } \\
\text { children. }\end{array}$ & $\begin{array}{l}\text { Siblings live farther away. } \\
\text { Little change between } 1986 \\
\text { and } 1995 .\end{array}$ \\
\hline
\end{tabular}

